\title{
Overview of Sandia National Laboratories and Antenna Development Department
}

by

Billy C. Brock

\begin{abstract}
General overview of Sandia National Laboratories and the Antenna Development Department
\end{abstract}

\section{DISCLAIMER}

This report was prepared as an account of work sponsored by an agency of the United States Government. Neither the United States Gnvernment nor any agency thereof, nor any of their employees, makes any warranty, express or implied, or assumes any legal liability or responsibility for the accuracy, completeness, or usefulness of any information, apparatus, product, or process disclosed, or represents that its use would not infringe privately owned rights. Reference herein to any specific commercial product, process, or service by trade name, trademark, manufacturer, or otherwise does not necessarily constitute or imply its endorsement, recommendation, or favoring by the United States Government or any agency thereof. The views and opinions of authors expressed herein do not necessarily state or reflect those of the United States Government or any agency thereof.

This work was supported by the United States Department of Energy under Contract DE-AC04-94AL85000 


\title{
Overview of Sandia National Laboratories and Antenna Development Department
}

\author{
Billy C. Brock
}

This work was supported by the United States Department of Energy under Contract DE-AC04-94AL85000. 


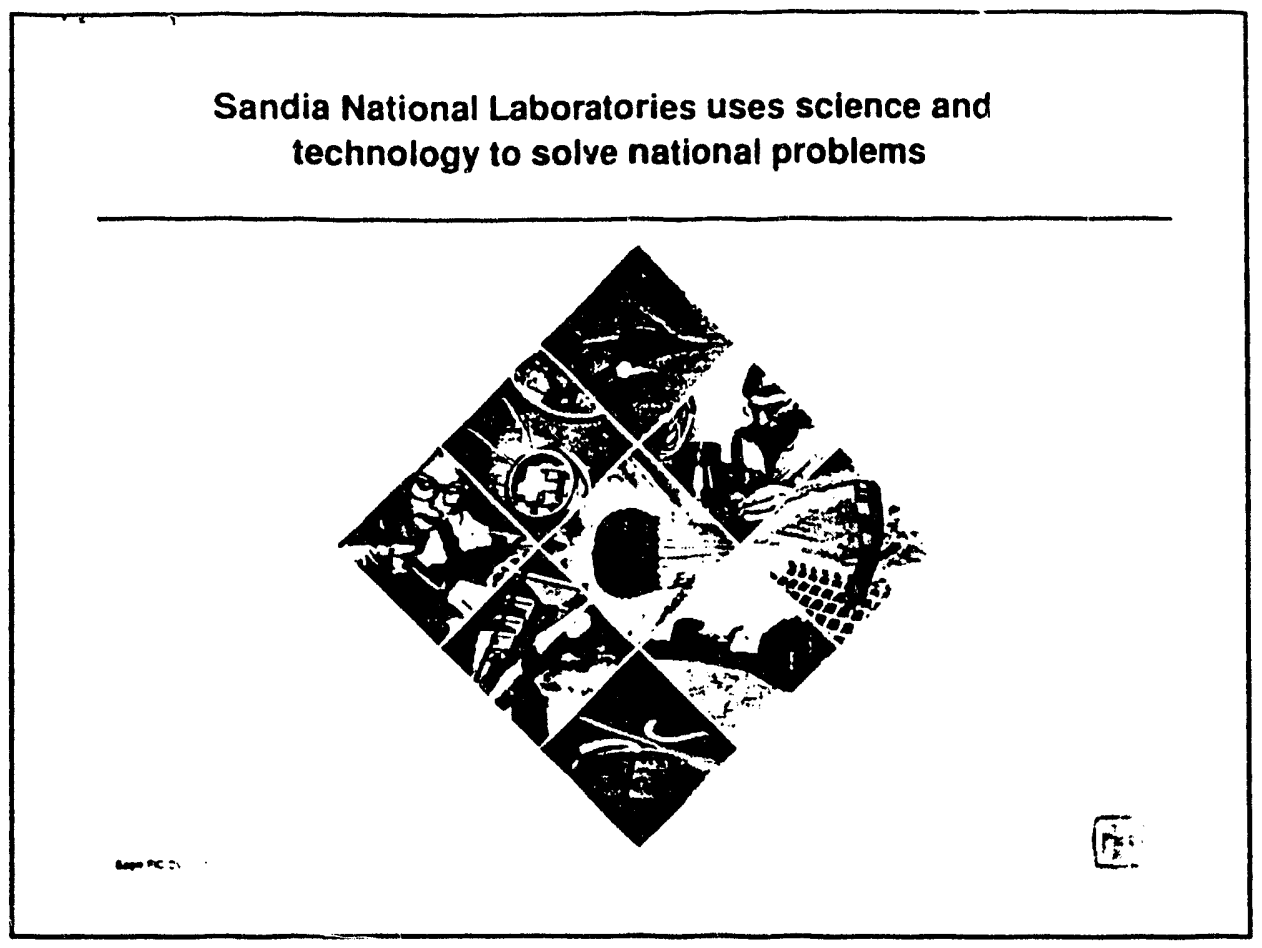

Sandia National Laboratories uses science and technology to solve national problems

- It is operated by Sandia Corporation, which was a wholly owned subsidiary of AT\&T from 1949 to 1993

- Sandia is a multiprogram R\&D laboratory

- Sandia has important nuclear weapon stewardship responsibilities

- Sandia carries a project from Research to Development to Application to solve problems in the national interest

Photos (clockwise from top, center last):

- An instrumented B83 bomb in a parachute dropped from a B-1B bomber; a Sandian preparing a turbine disc on a robotic deburring system; the heliostat field and receiver tower at the National Solar Thermal Test Facility; the RATLER robot that can negotiate extremely rugged or interplanetary surfaces; ultraviolet laser beams used to study a methane-air flame at the Combustion Research Facility in California; a Z rocket at Sandia's launch facility on Kauai; a Sandian injecting polyurethane into a closed aluminum mold; a silicon chip that can detect a variety of chemicals; and a color schlieren photograph showing the shock wave in the flow field around a ribbon parachute in a wind tunnel 


\section{Sandia has a long history of service to the nation}

\section{"Exceptional Service in the National Interest"}

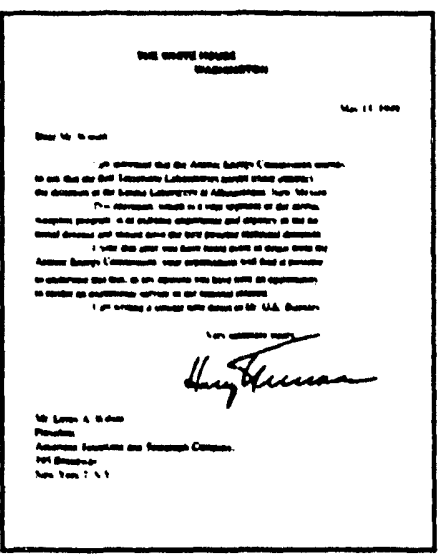

\section{Sandia has a long history of service to the nation}

- Established in 1949

- Strategic intent born on May 13, 1949 in letter from President Truman that called for "exceptional service in the national interest"

- Original mission: Nuclear weapon engineering

- Modeled after AT\&T Bell Laboratories

- Science and technology with strong mission focus

- Good corporate citizen with extensive state and local outreach activities

- In 1973, we became a multiprogram R\&D laboratory; in 1979 we became a DOE National Laboratory, with responsibilities in

- Defense

- Energy and Environment

- In 1989, the National Competitiveness Technology Transfer Act added another responsibility

- Contributions to industrial competitiveness

- National priorities and expectations are changing, with increasing emphasis on private sector teaming 
Sandia works with its customers to achieve national goals
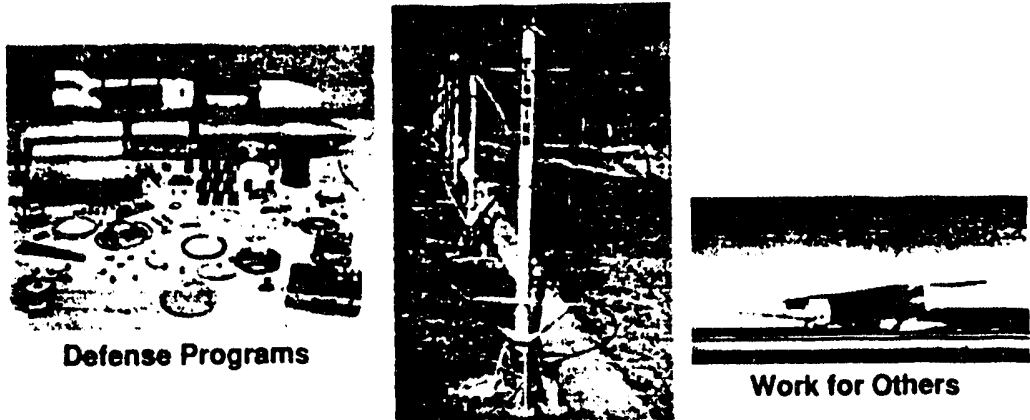

Energy and

Environment

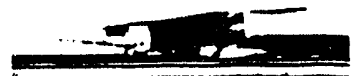

Work for Others

Sandia works with its customers to achieve national goals

- Defense Programs (DOE, DoD)

- Nuclear weapon stockpile stewardship

- New approaches to weapon production

- Arms control, non-proliferation, and intelligence

- Photo: B83 strategic bomb laid out with parts

- Energy and Environment (DOE, NRC)

- Efficient, safe, environmentally compatible energy conversion and utilization

- Waste management solutions

- Photo: Vertical-axis wind turbines

- Work for others

- R\&D for other government agencies (DoD, NSA, etc.)

- Photo: Rocket sled test 
Sandia's responsibilities are expanding

to meet national needs

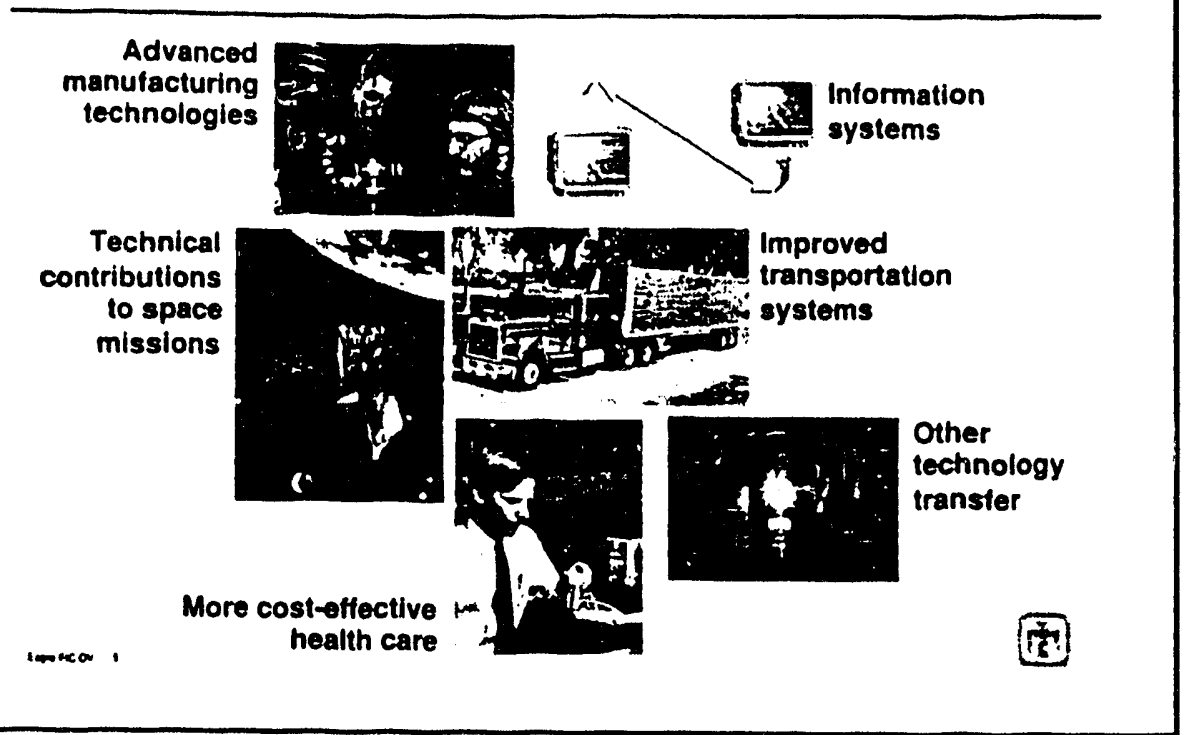

Sandia's responsibilities are expanding to meet national needs

Sandia is making contributions to the global competitiveness of US industries through partnerships in

- Advanced manufacturing technologies

- Sandia's Center for Advanced Manufacturing Technology

- Other major support facilities are the Integrated Manufacturing Technologies Laboratory in California, the Process Development Lab, Microelectronics Lab, CSRL, IMRL, RMS\&EL, Microelectronics Quality/Reliability Center

- Participant in the Agile Manufacturing Enterprise Forum

- Improved transportation systems

- Technical contributions to space missions

- More cost-effective health care

- Information systems

- Other technology transfer

- Sandia signed 62 Cooperative Research and Development Agreements with industry in the first year alone, representing a total investment of $\$ 147$ million

-Photos (counterclockwise from top left): Edge-finishing robot; Global Positioning Satellite; non-invasive glucose monitor; FASTCAST computerized investment casting process; Safe, Secure Transport; and concurrent engineering 
Sandia undertakes new programs that enhance national security and industrial competitiveness

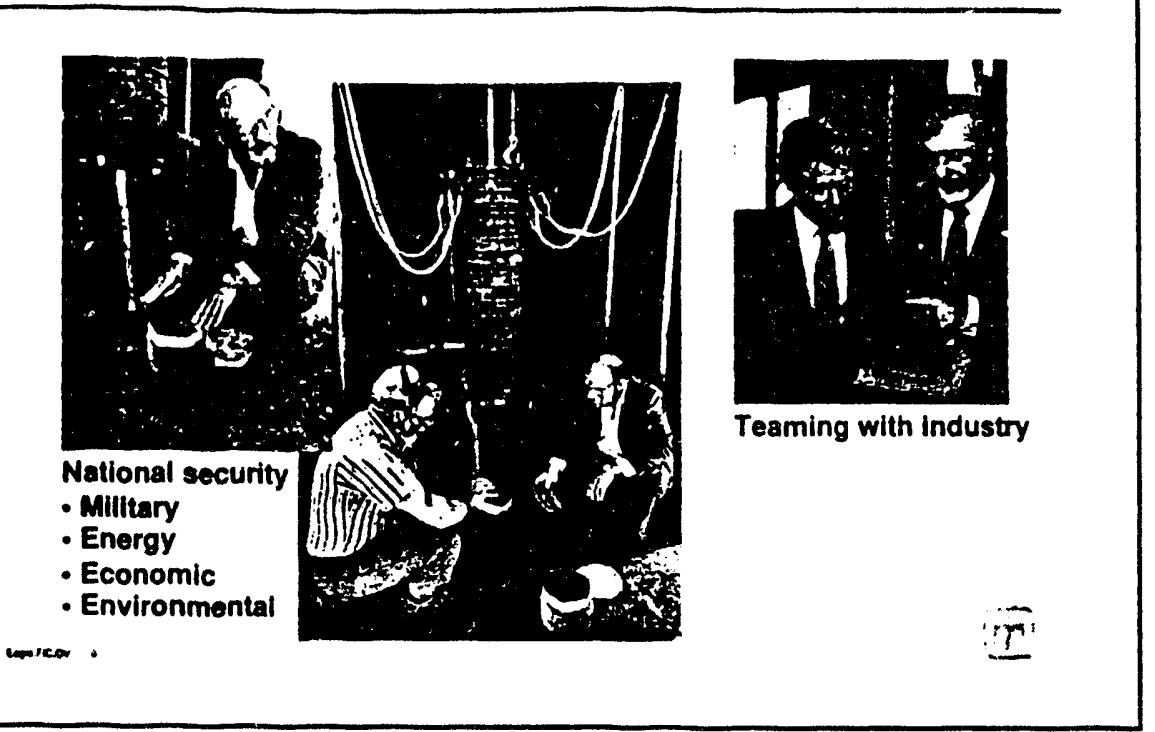

\section{Sandia undertakes new programs that enhance national security and industrial competitiveness}

We have developed a set of priorities for undertaking new programs based on national security (military, energy, economic, environmental) and teaming with industry. These priorities enable us to

- Respond rapidly to national emergencies (such as the Persian Gulf conflict)

- Build on and strengthen Sandia's core competencies and other essential Laboratory capabilities

- Proactively help customeis invent their future

- Provide strategic teaming opportunities with industry and universities

- Create Sandia program synergies

Our commitment is to build on the achievements of Sandia's past with increased customer focus

Photos: Sandia researchers (left and center) conduct USS lowa investigation to determine likely cause of explosion; a not-yet-elected President Bill Clinton (right) receives a printed circuit board made with environmentally friendly manufacturing technology from Sandia President Al Narath 


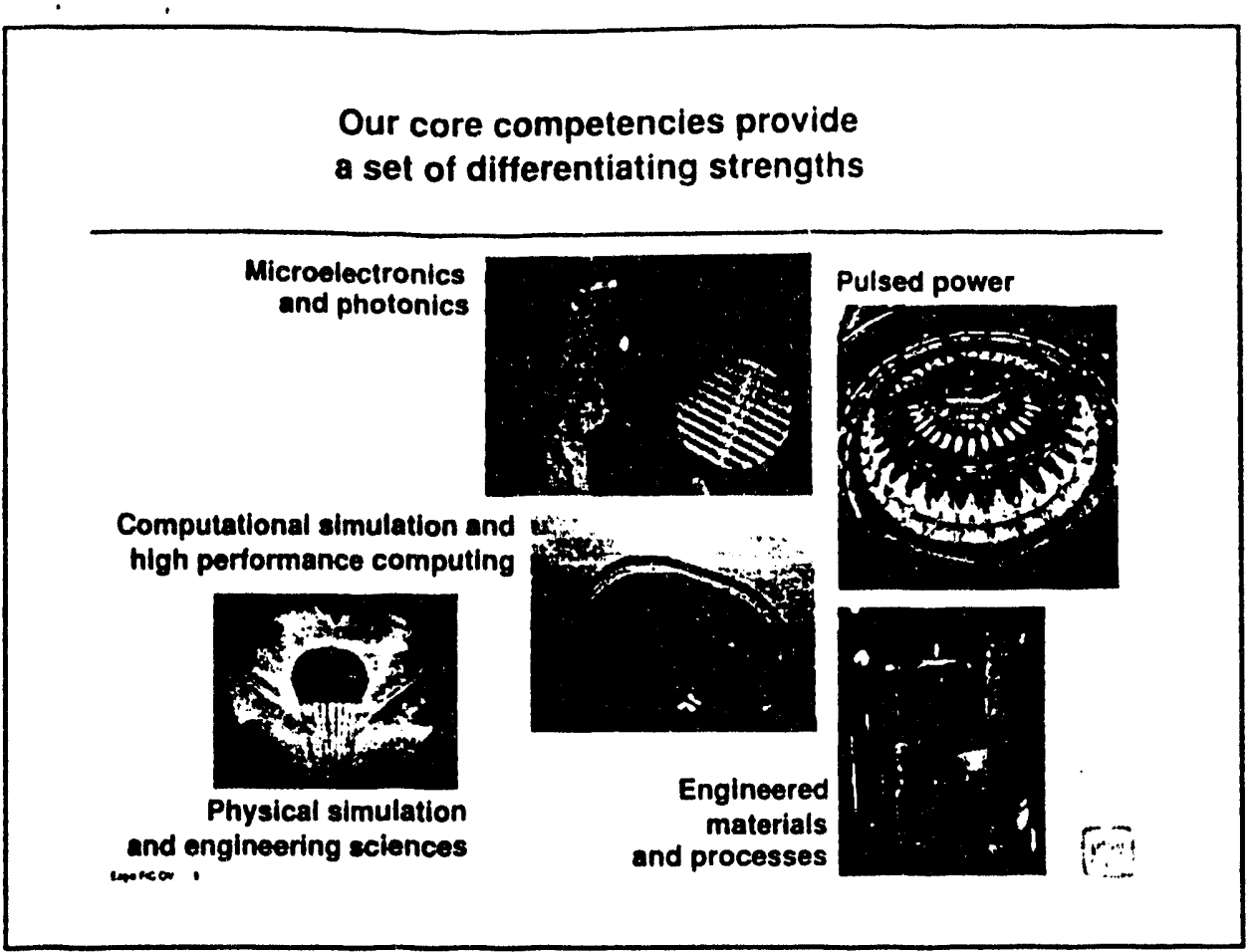

Our core competencies provide a set of differentiating strengths

Diversification has provided a "real-world" experience base in a variety of key areas known as core competencies

- Microelectronics and Photonics. Photo: A Sandian displays a wafer of semiconductor chips manufactured in the Microelectronics Development Laboratory

- Computational Simulation and High Performance Computing. Photo: Magnetic resonance imaging shows a slice of the human brain

- Physical Simulation and Engineering Sciences. Photo: Shock wave structure in the flow field surrounds an 18-inch-diameter model of a ribbon parachute at Mach 1.9 in a NASA wind tunnel

- Engineered Materials and Processes. Photo: Experiment examines chemical vapor deposition (CVD) process

- Pulsed Power. Photo: Sandia's Particle Beam Fusion Accelerator runs an experiment aimed at achieving fusion, the energy that powers the sun, in the laboratory

These core competencies are the distinguishing integration of skills, technologies, knowledge, and facilities used by Sandia to achieve its strategic goals and objectives. Core competencies take us beyond science to solutions. They form the basis for much of Sandia's work with industry 
Core support transforms innovations into useful products

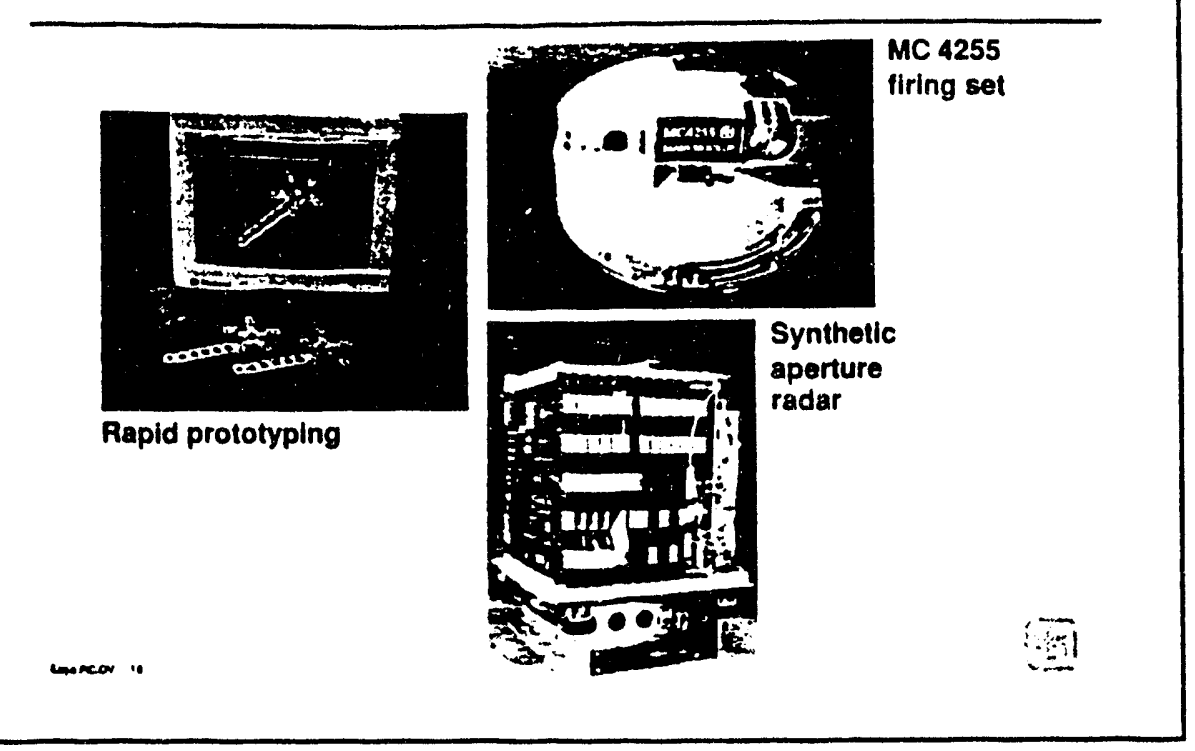

Core support transforms innovations into useful products

\section{Examples:}

- Rapid prototyping

- Defense Programs (nuclear weapons complex reconfiguration)

- Work for Others (space applications)

- Energy and Environment (environmentally conscious manufacturing)

- MC 4255 firing set

- Defense Programs (W 91/MAST)

- Work for Others (conventional weapons)

- Energy and Environment (precisely timed blasting)

- Synthetic aperture radar

- Defense Programs (guidance \& navigation)

- Work for Others (reconnaissance/targeting)

- Energy and Environment (oil spill mapping) 
The Defense Programs Sector has several key program areas

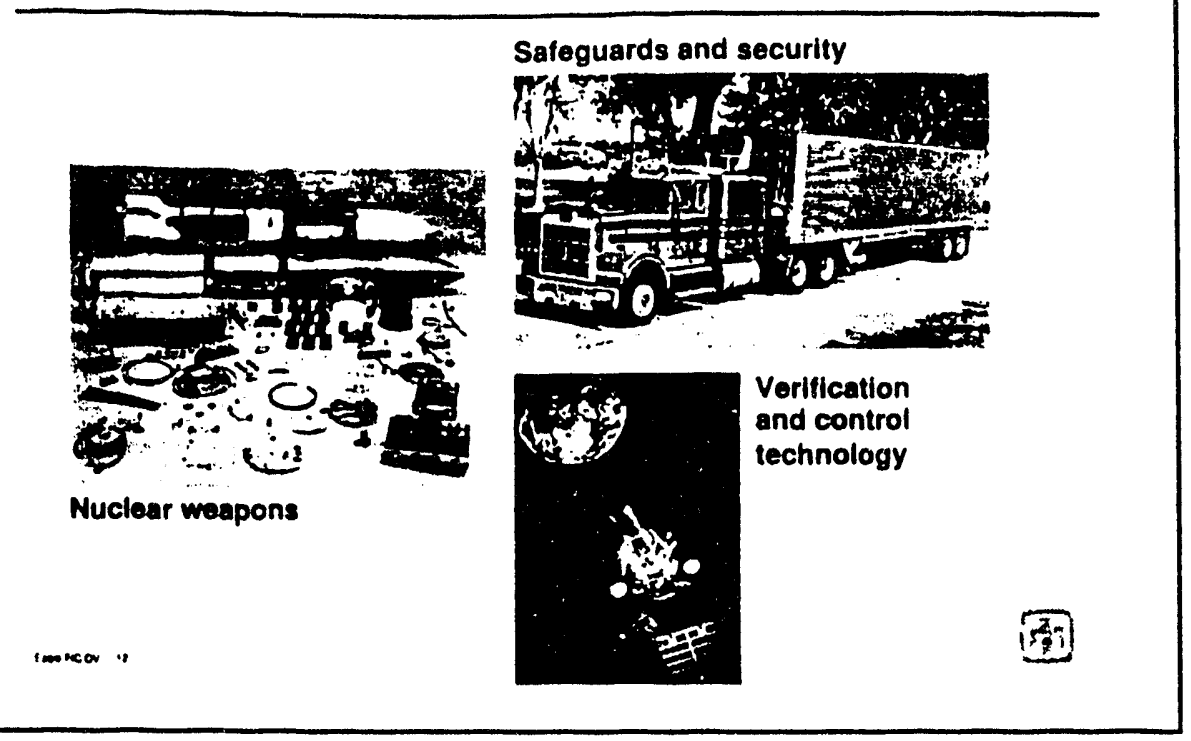

The Defense Programs Sector has several key program areas

- Nuclear Weapons. Photo: B83 bomb laid out with parts

- Safeguards and Security. Photo: Safe, Secure Transport

- Verification and Control Technology. Photo: VELA satellite Our primary mission is the "weaponization" of nuclear explosives

- Design, engineering, testing, integration, and production interface for non-nuclear components

- "Cradle-to-grave" responsibility for US nuclear weapons

- Defense programs are a significant fraction of the laboratories' activities, and accounted for $\$ 747.2$ million of taxpayer investment in 1992

Sandia has 30 years of experience in arms control, treaty verification, and proliferation detection

- Satellite and seismic nuclear burst monitoring

- Safeguards for the non-proliferation treaty

- Continuous monitoring systems and technologies for INF and START

- Data fusion and technical analysis of information from technical sensors and other sources 
The Energy and Environment Sector has four major program areas
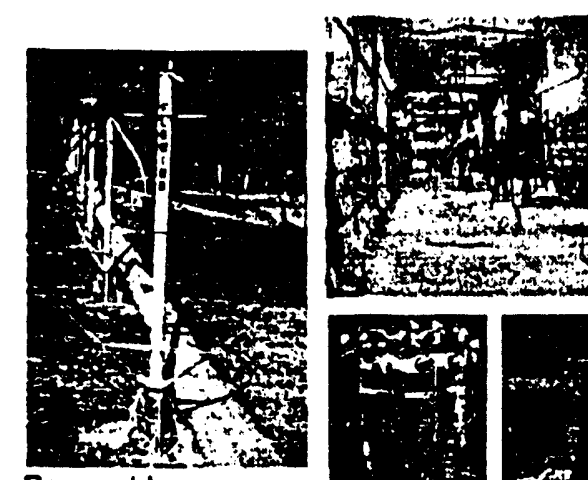

Environmental R\&D/ waste management

Renewable energy
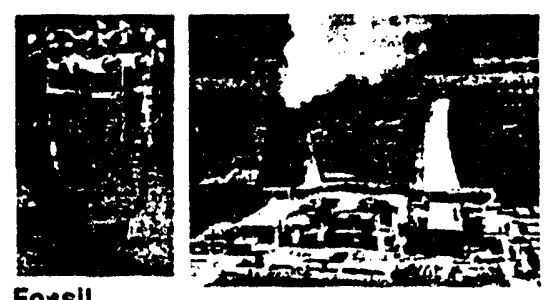

Nuclear

energy

coner is

Fossil

energy

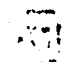

The Energy and Environment Sector has four major program areas

- Renewable Energy. Photo: Vertical-axis wind turbines

- Photovoltaic. solar thermal, wind energy

- Fossil Energy. Photo: Polycrystalline diamond drill bits designed at Sandia, now in widespread use

- Technical collaboration with industry

- Nuclear Energy. Photo: Nuclear reactors

- Implementation of safe, efficient nuclear power systems

- Environmental R\&D Waste Management. Photo: Cavern at Waste Isolation Pilot Plant

- Restoration of existing environmental problems, minimization of future impacts, hazardous material transportation

- Ties with industry, international technology exchange

- Nuclear waste management (WIPP, Yucca Mountain, NTS)

- Funding for Energy \& Environment Sector programs is on the increase, and totaled $\$ 262$ million in 1992 
The Work for Others Sector

includes many programs

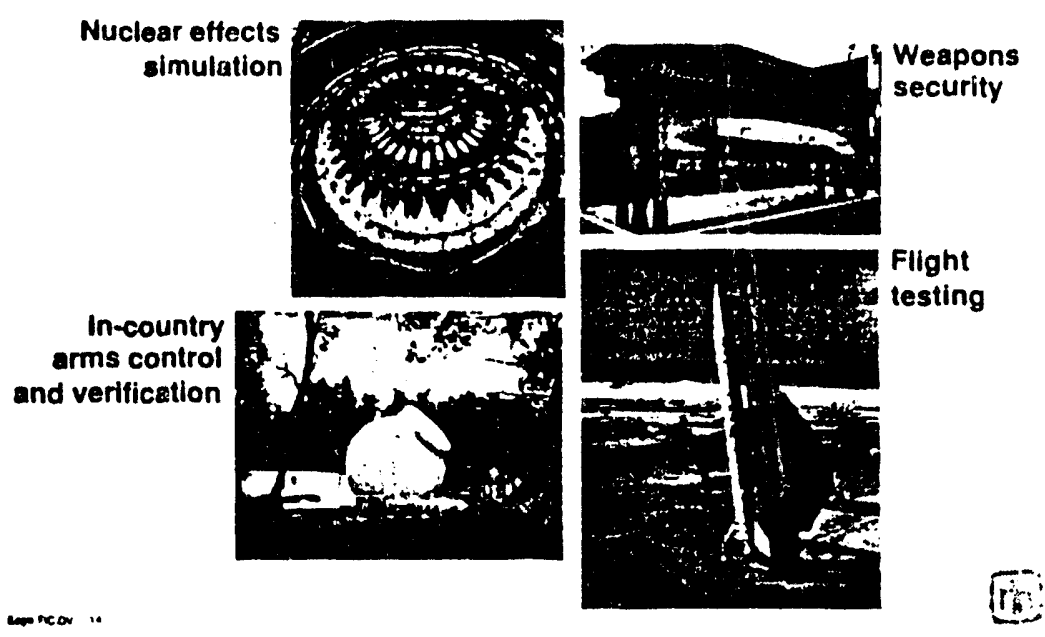

The Work for Others Sector includes many programs

The Work for Others Sector includes many programs that make Sandia's unique capabilities and facilities available to federal agencies and non-federal entities

- Nuclear Effects Simulation. Photo: Particle Beam Fusion Accelerator

- In-Country Arms Control and Verification. Photo: Unmanned seismic stations (installed throughout US and Canada)

- Weapons Security.

Photo: Weapons storage vault (protection from small-arms fire)

- Flight Testing. Photo: Strypi rocket launch at Kauai

- Arming, Fuzing, Firing Systems

- Advanced Chemical Munitions

Customers include

- DoD (75 percent of funding in this sector)

- Air Force, Navy, Army, NRC, DNA, DARPA, and others

- Reimbursable projects totaled \$359 million in 1992

Technologies

- Aerospace systems

- Precision strike technology

- Remote sensing and verification

- Development testing of new systems 


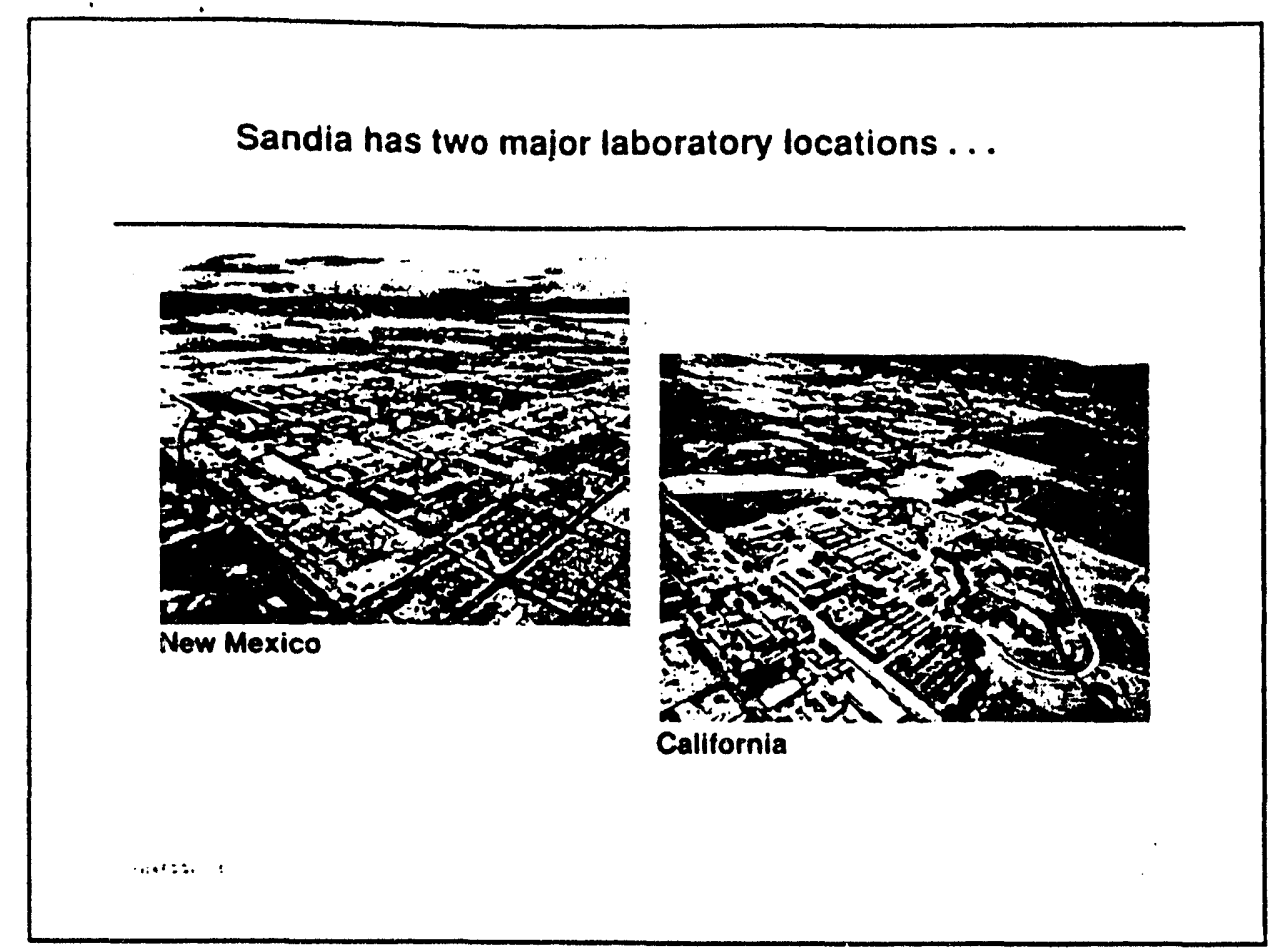

Sandia has two major laboratory locations ...

- Sandia/New Mexico

- On Kirtland Air Force Base, southeast of Albuquerque

- 17,750 acres, 556 major buildings, 4.6 million gross square feet

- $\$ 1.1$ billion US government investment

$-7,400$ employees

- Sandia/California

- In Livermore, 40 miles east of San Francisco

-413 acres. 58 major ouildings, 710,000 gross square feet

- \$265 million US government investment

$-1,000$ employees

Sandia's unique facilities are a national resource

- Pulsed power accelerators, reactor facilities

- Computing facilities. robotics labs

- Solar thermal facilities. environmental and field test facilities

- Combustion Research Facility

- Semiconductor materials facilities 

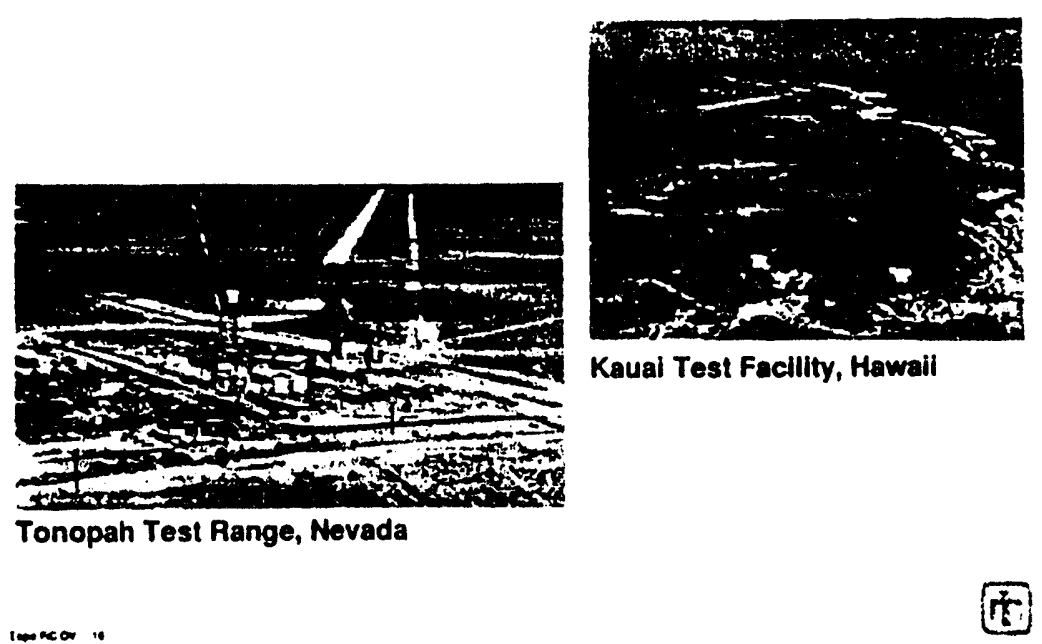

\section{$\ldots$ and two flight testing locations}

- Tonopah Test Range, Nevada

- On Nellis AFB

- 525 square miles, 98 major buildings, 159,000 gross square feet

- \$85 million US government investment

-50 employees

- Kauai Test Facility, Hawaii

- On Navy Pacific Missile Range

-275 acres, 25 major buildings, 41,000 gross square feet

- $\$ 30$ million US government investment

-5 employees 


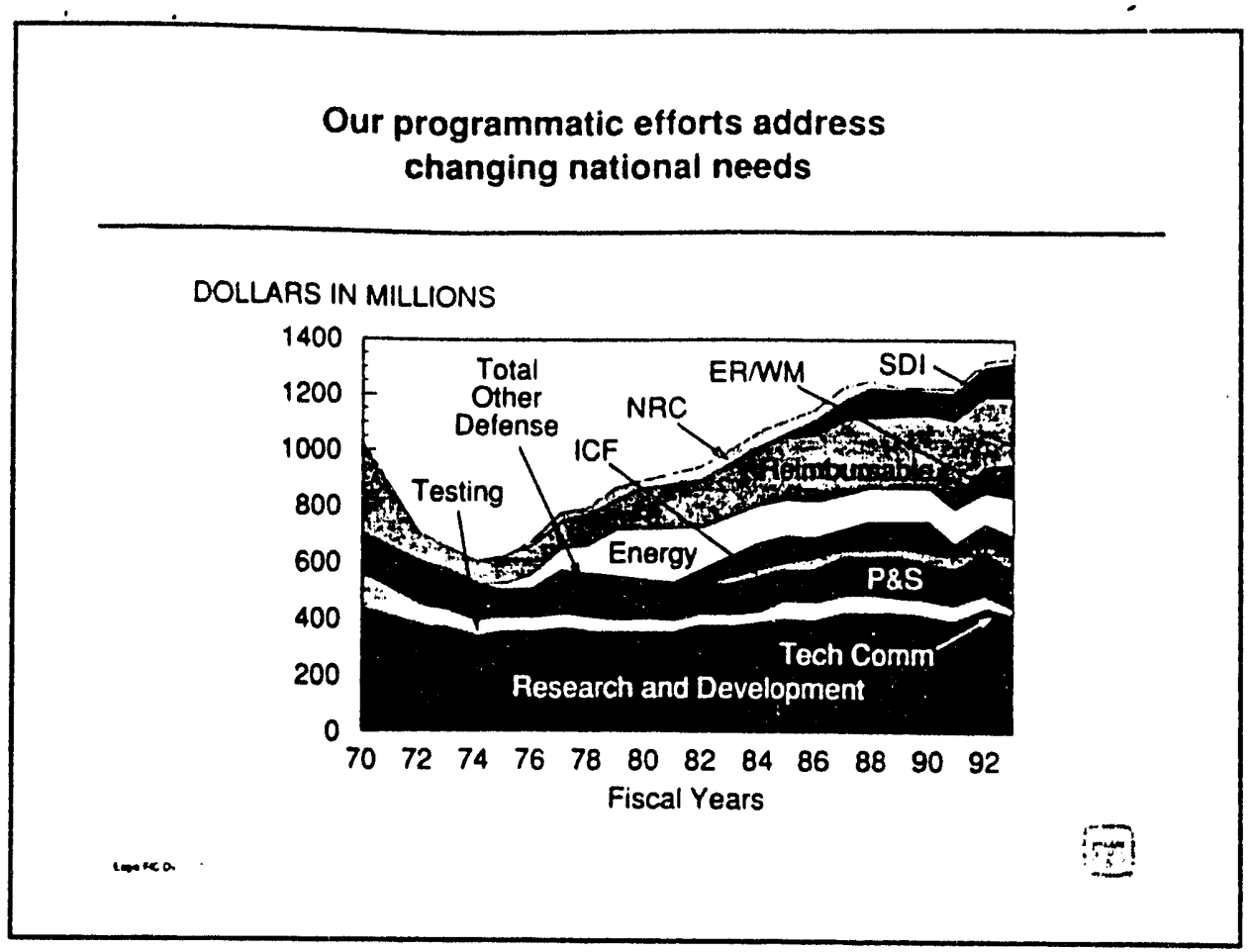

Our programmatic efforts address changing national needs

Our programmatic efforts address changing national needs in

- Energy

- Defense

- Production and surveillance

- Testing

- Inertial confinement fusion

- Research and development

Abbreviations:

NRC Nuclear Regulatory Commission

ICF Inertial Confinement Fusion

SDI Strategic Defense Initiative

P\&S Production and Surveillance

Tech Comm Technology Commercialization

ER/WM Environmental Restoration/Waste Management 
Our staffing levels reflect changing national needs

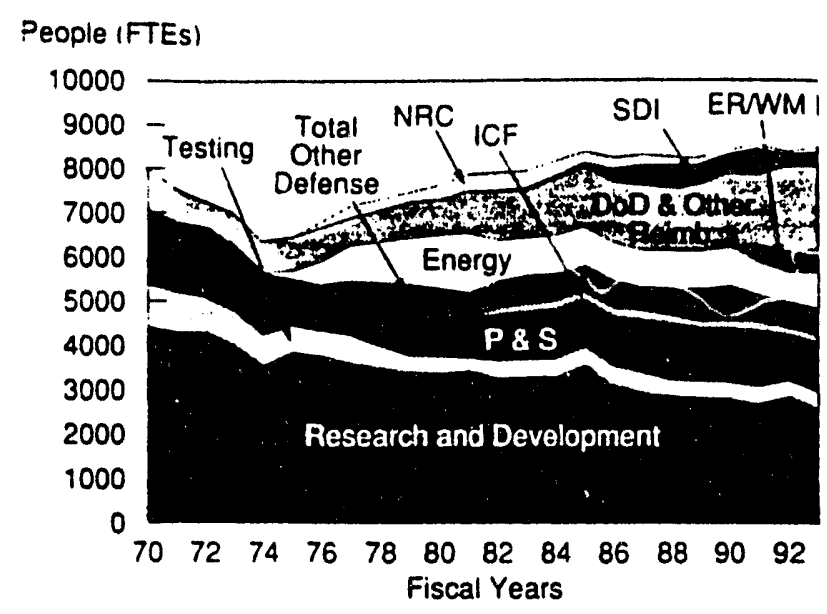

Our staffing levels reflect changing national needs

Our staffing levels reflect changing national needs in

- Energy

- Defense

- Production and surveillance

- Testing

- Inertial confinement fusion

- Research and development

Abbreviations:

NRC Nuclear Regulatory Commission

ICF Inertial Confinement Fusion

SDI Strategic Defense Initiative

P\&S Production and Surveillance

ER/WM Environmental Restoration/Waste Management 
Engineering and physical sciences are the backbone of our multidiscipline laboratories

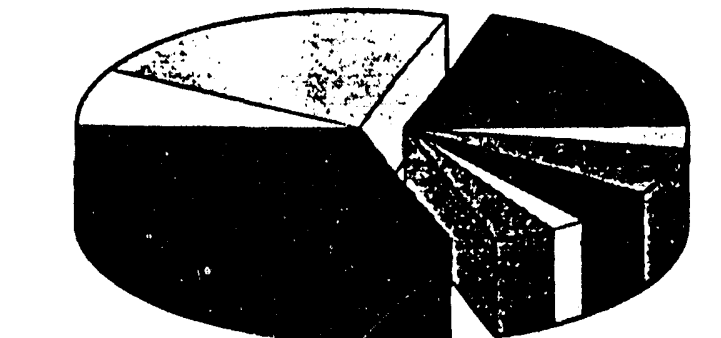

Support

$\square$ Other Prolessionals

$\square$ Technicians

- Computer Science

- Electrical Engineering

Other Engineering

Physics

0 Chemistry

Mechanical Engineering

Other Science

Engineering and physical sciences are the backbone of our multidiscipline laboratories

- Our technical professionals have predominantly advanced degrees in engineering and science

- More than three-fourths of our 3,676 technical professionals hold master's degrees or doctorates in their fields ( $43 \%$ Masters, $37 \% \mathrm{PhD}$ )

- More than half of our technical professionals are engineers

- Technical professionals make up 43 percent of our work force, technical associates 20 percent, administrative professionals 11 percent, management associates 8 percent, and represented employees 18 percent (not including 1,632 on-site contractors)

- Our 915 administrative professionals have predominantly advanced degrees in business 


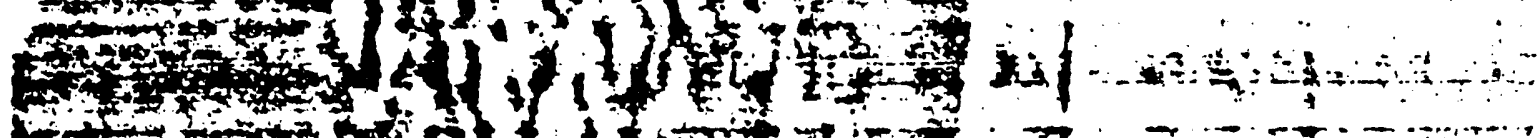

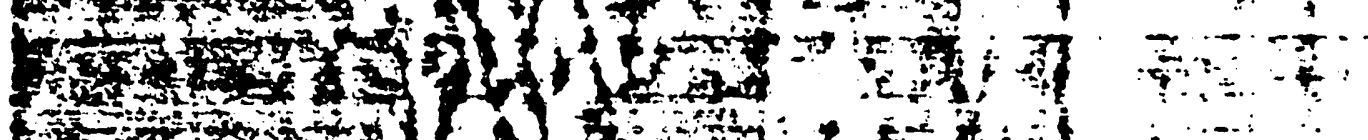

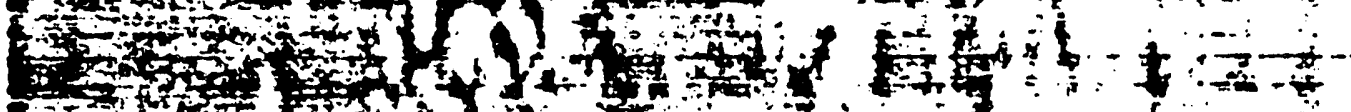

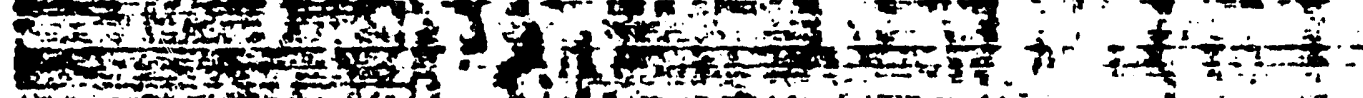

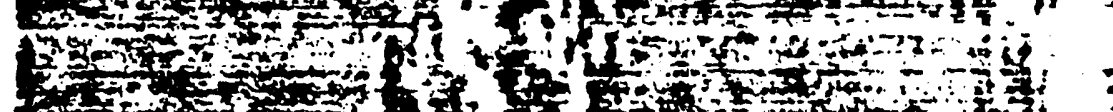

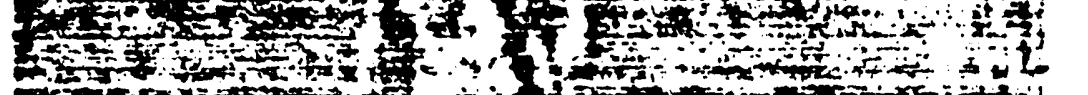

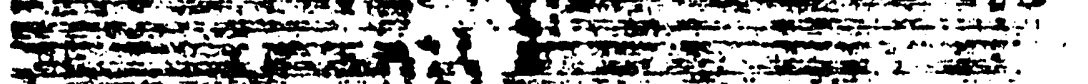
FT

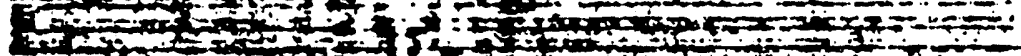

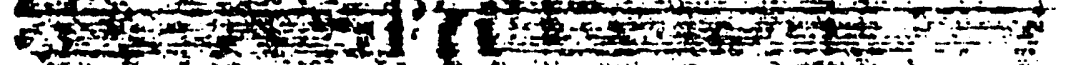

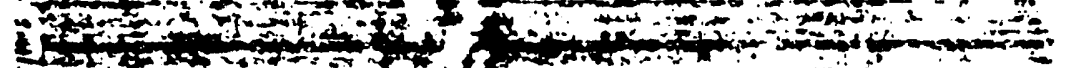

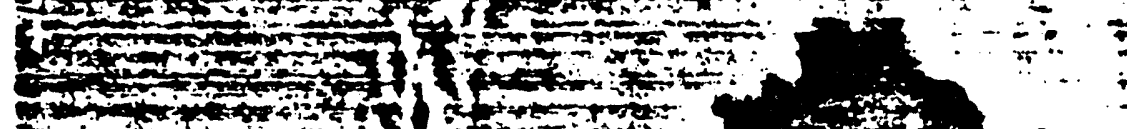

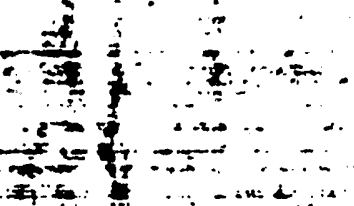

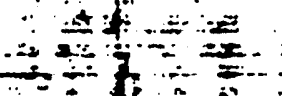

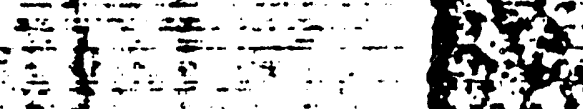

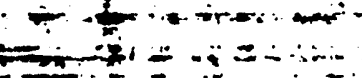

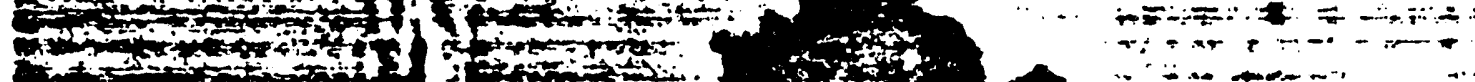

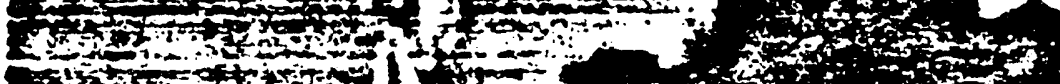

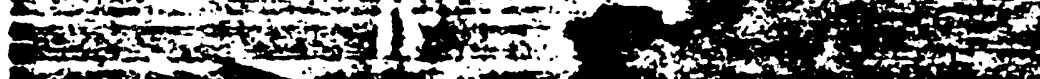
ben

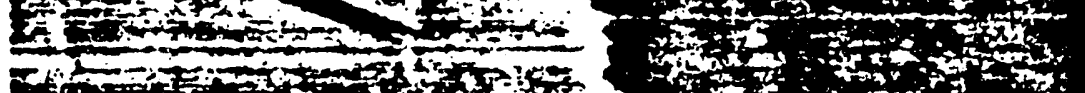
Fom

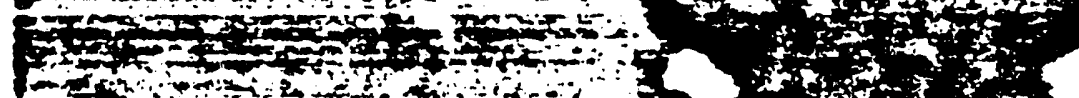

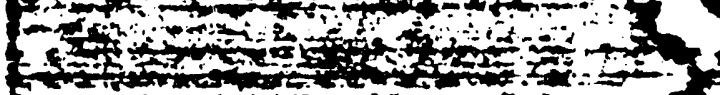
and

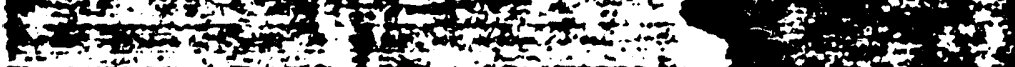

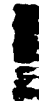

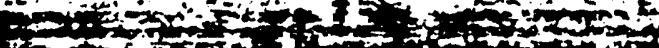

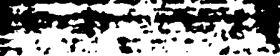

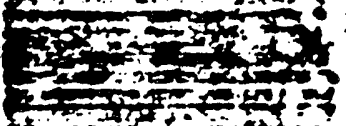

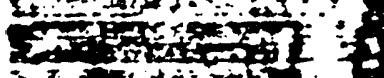

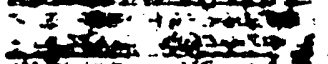
4 $29+x^{2}=2+2$

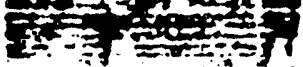

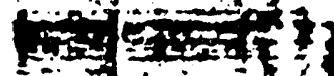
50 and

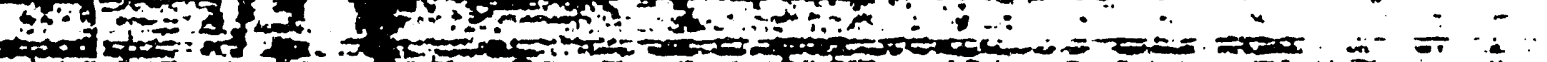

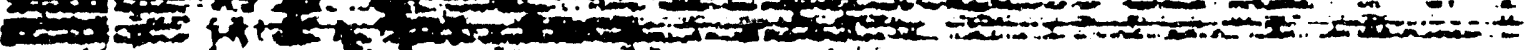

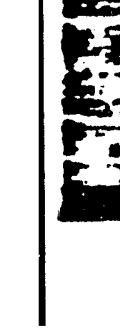




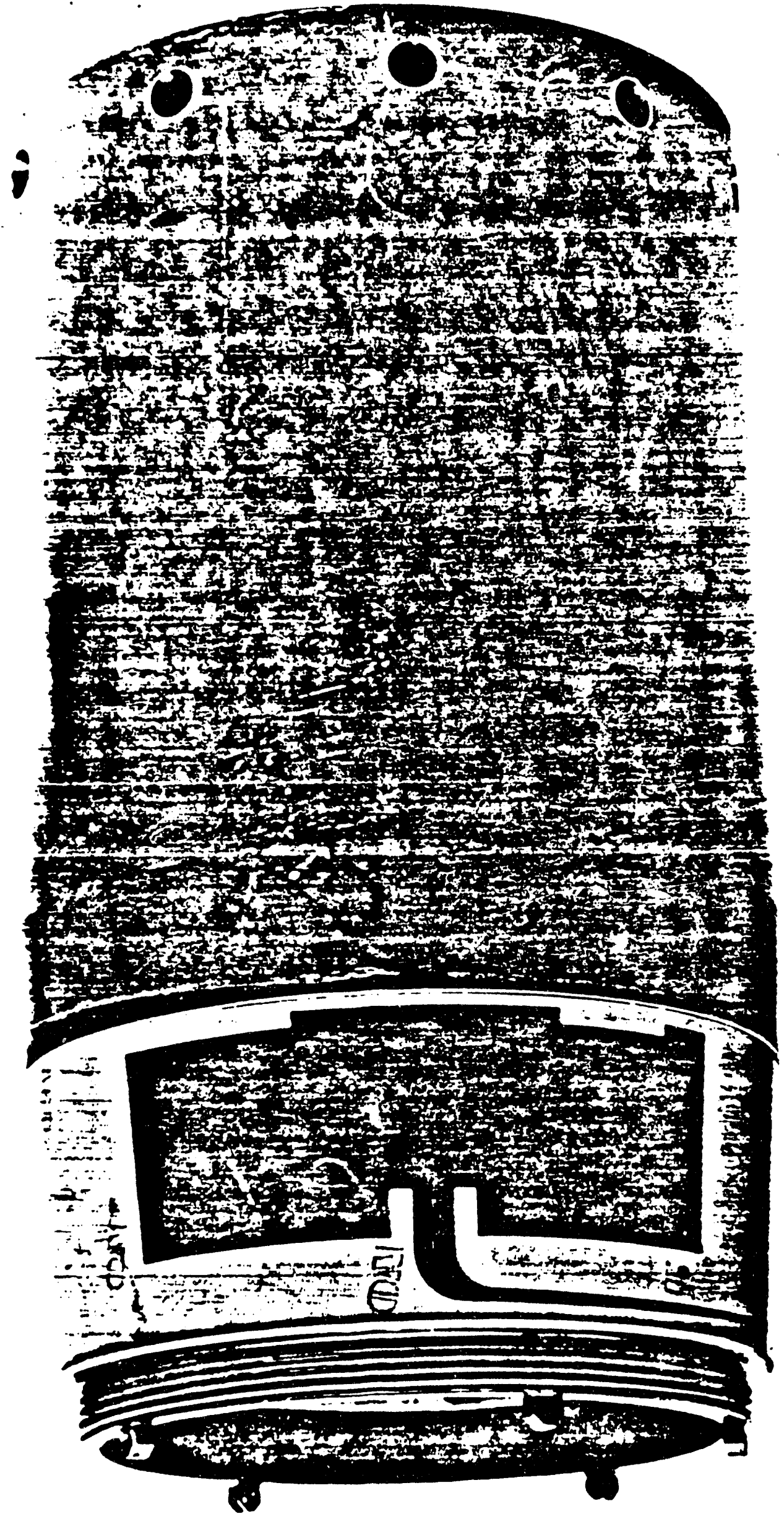




\section{Reentry Vehicle Antennas}

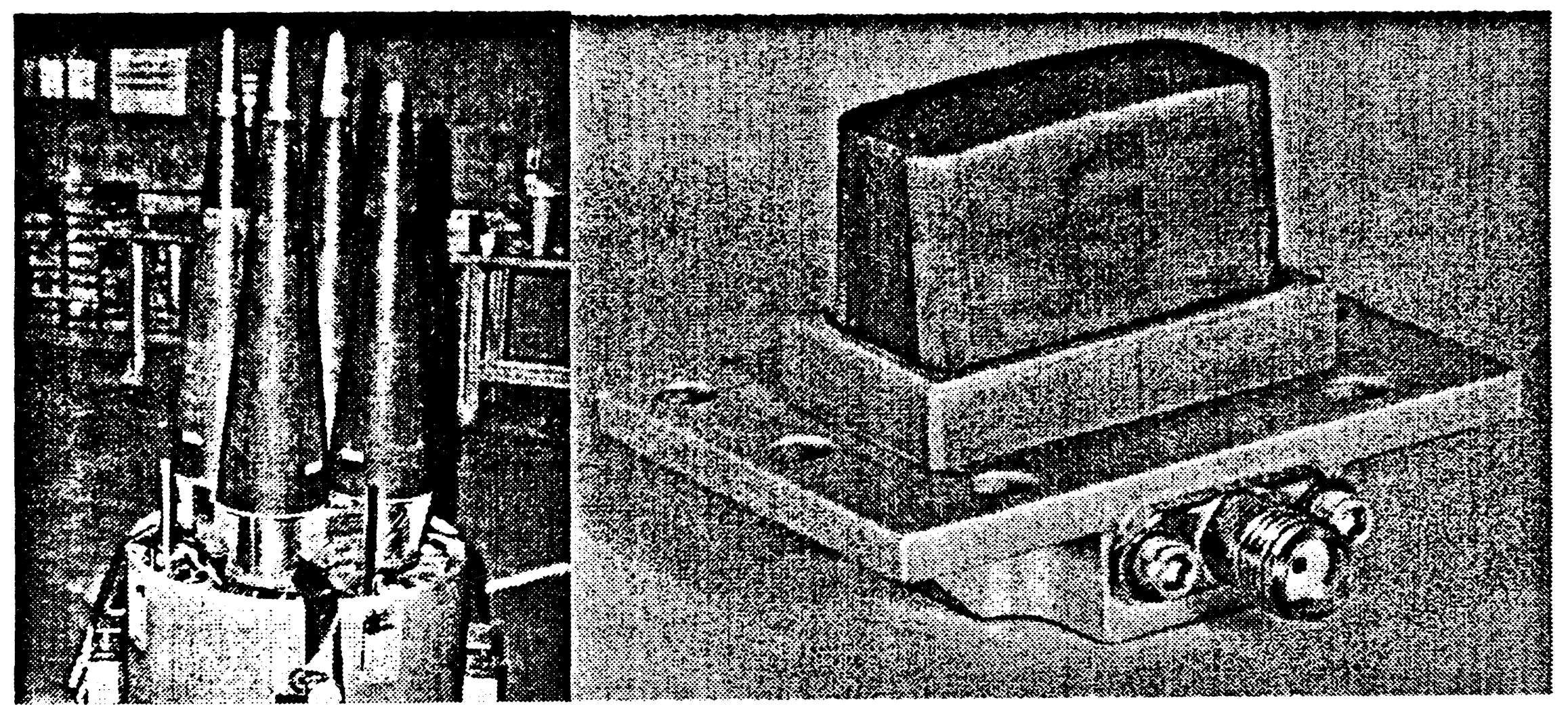

Antenna Development Department 


\section{Rocket Antennas}

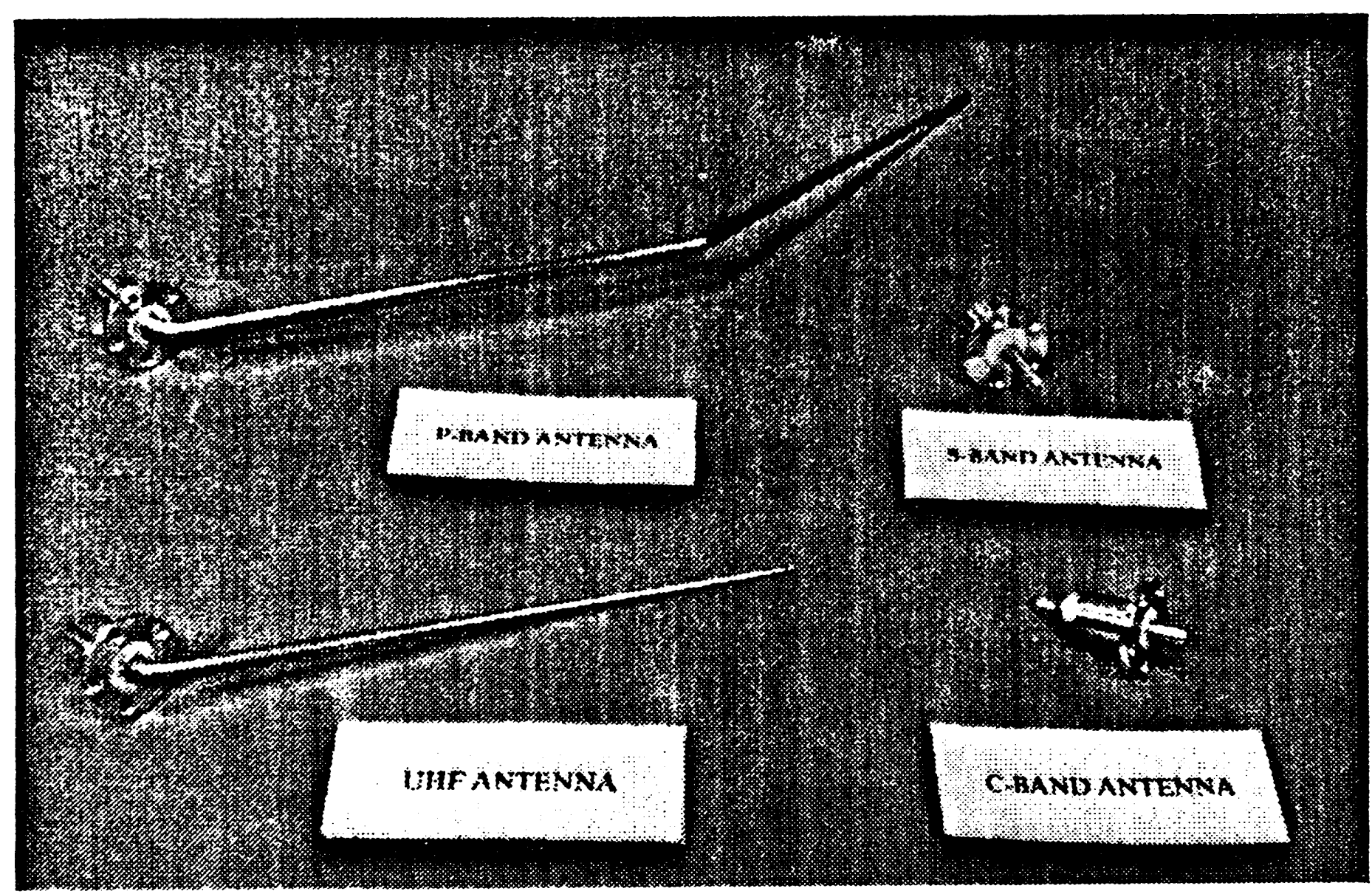




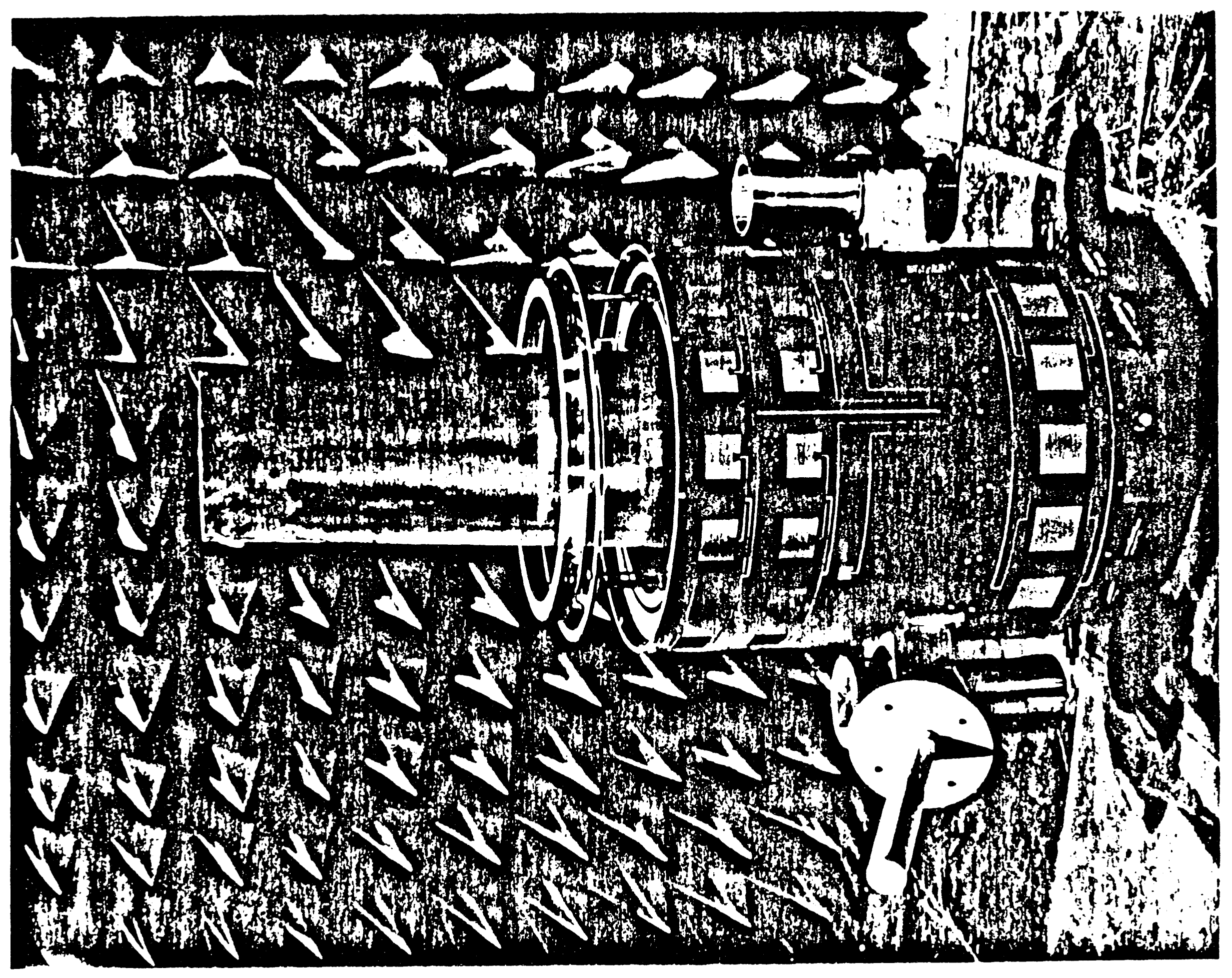




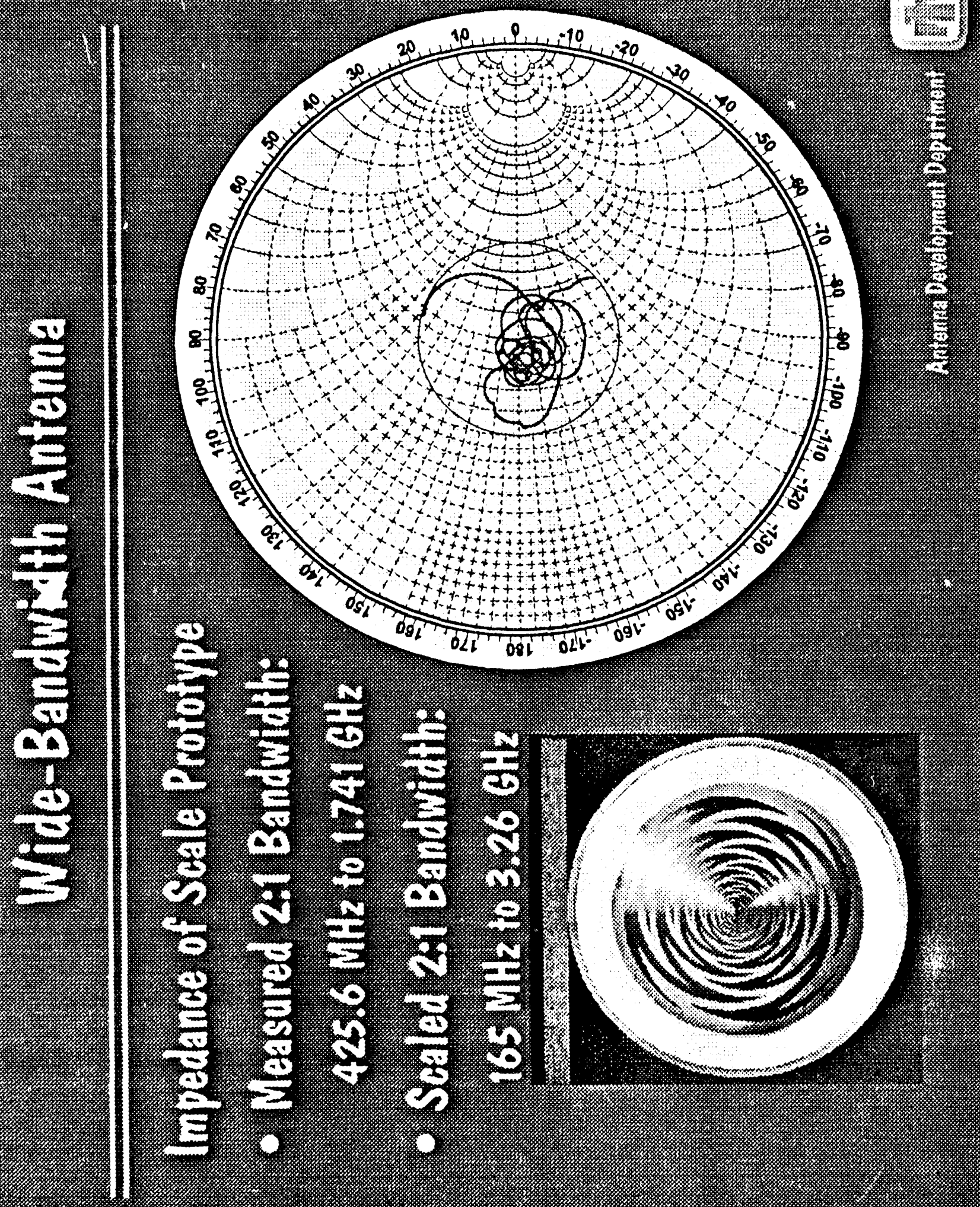




\section{TFS Phased Array Antenna}

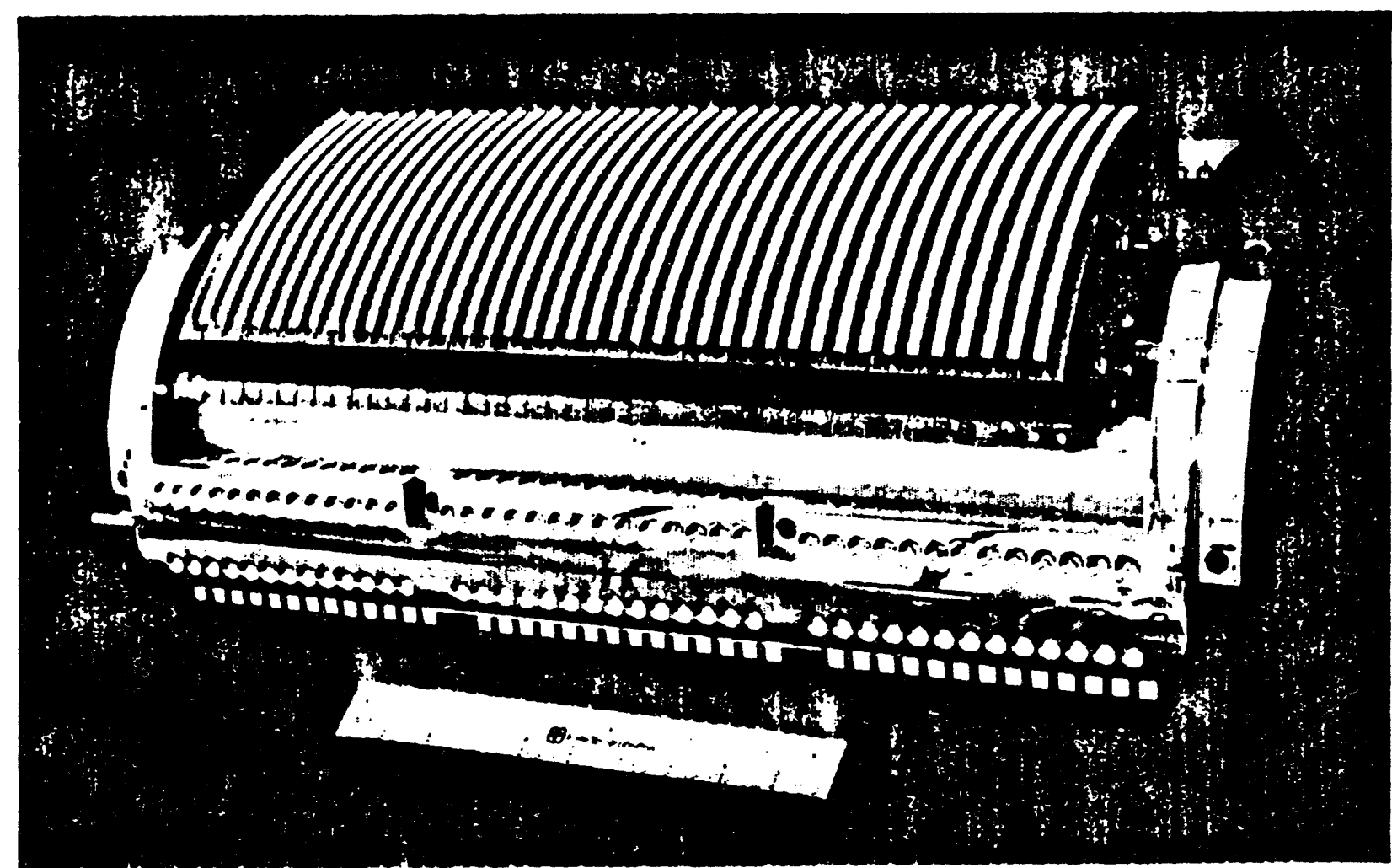

- Frequency: $15 \pm 0.5 \mathrm{GHz}$

- Elements: 80 (2/row $\times 40$ rows)

- Phase Control: Two T/R modules per row

- Beam Scanning: $\pm 15^{\circ}$ along track
- Monopulse Beam Forming: Along track

- Dimensions: $26 \mathrm{~cm} \mathrm{x} 48 \mathrm{~cm}$

- Gain: $30 \mathrm{dBi}$

- Beam Width: $3^{\circ} \times 5^{\circ}$ 


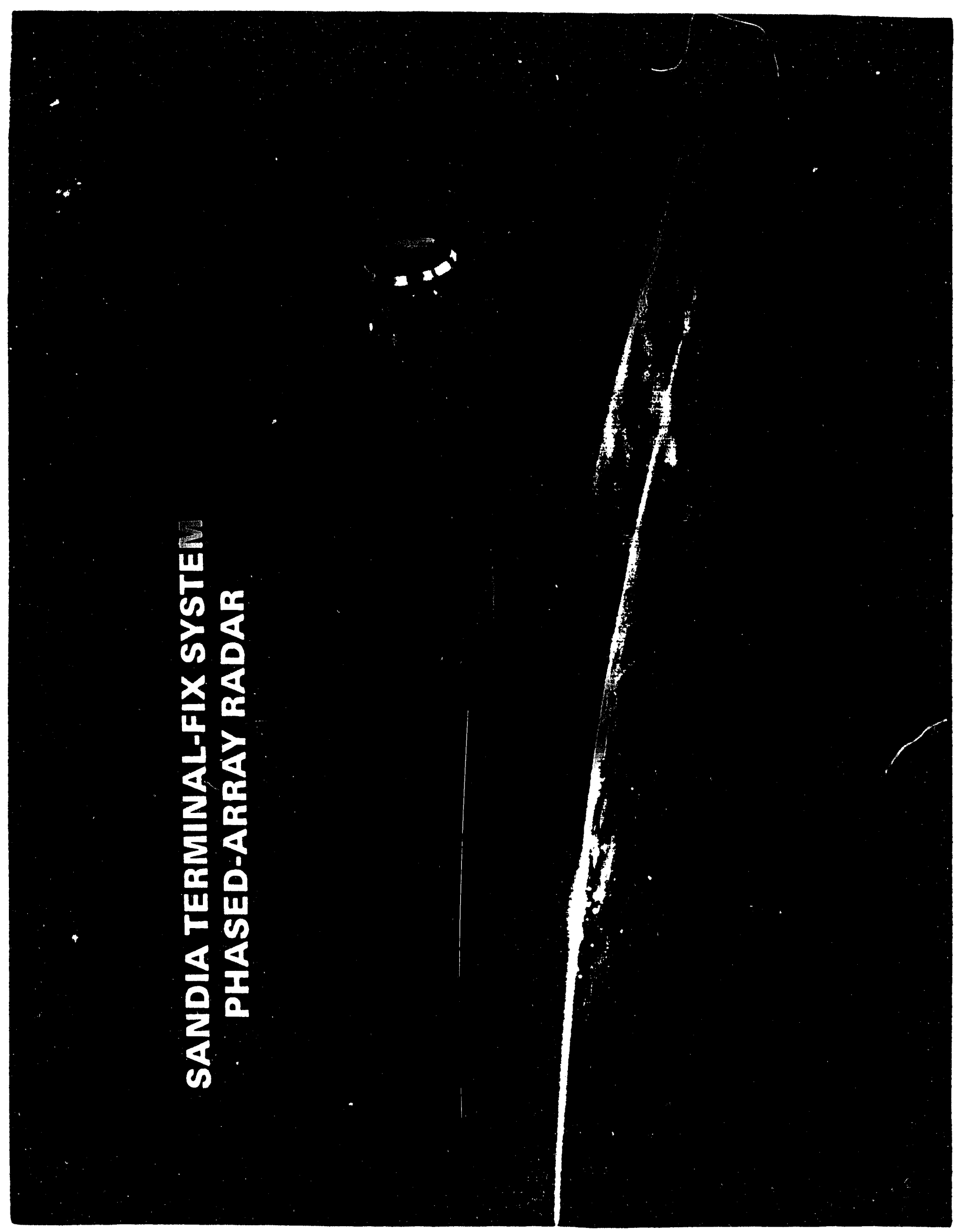




\section{5-GHz SAR Antenna}

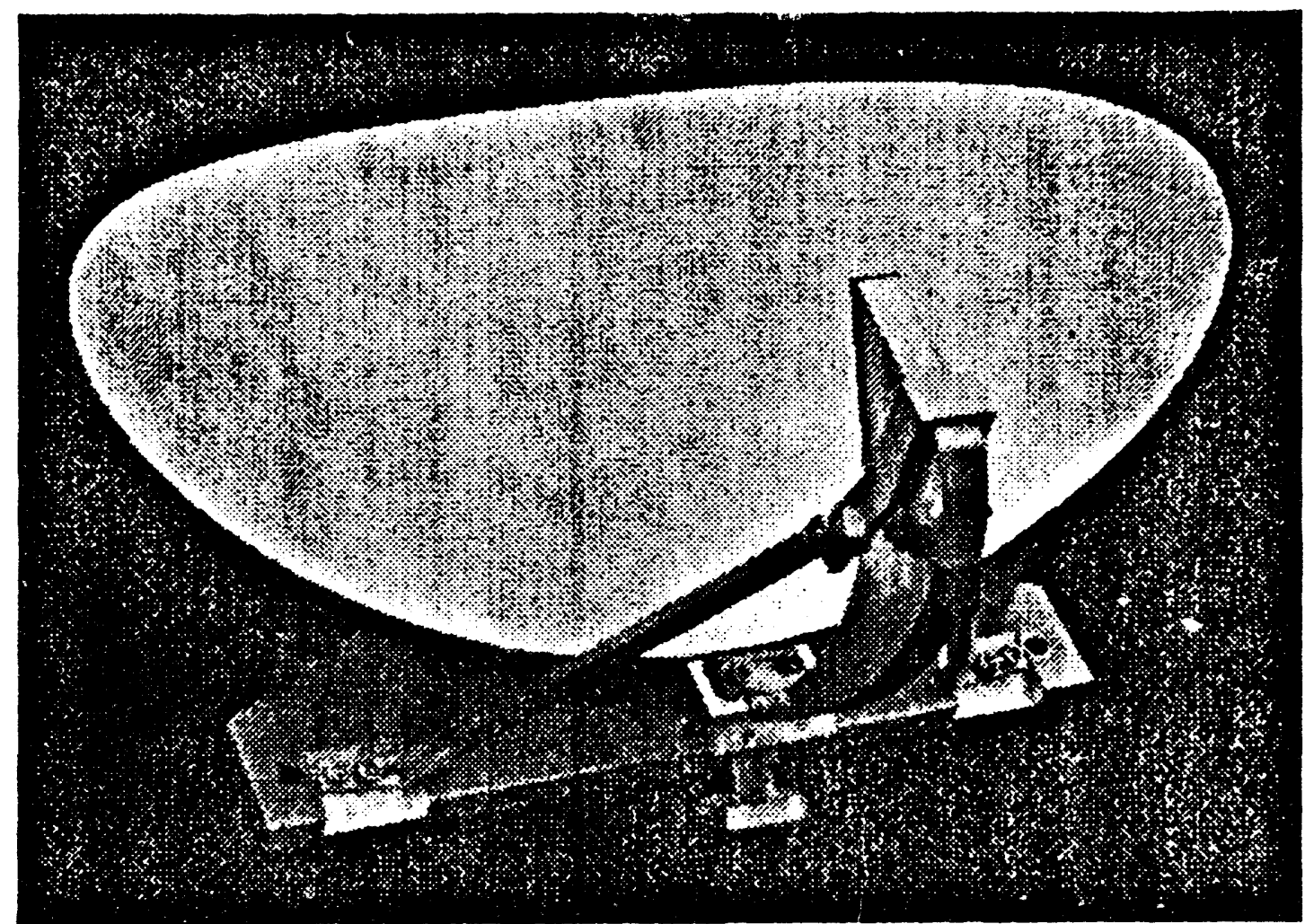

- Offset-fed Parabolic Reflector

- Gain: 31 dBi
- Beamwidth: 2 by 5 Degrees

- Wide Bandwidth 


\section{SAR Antenna Development}
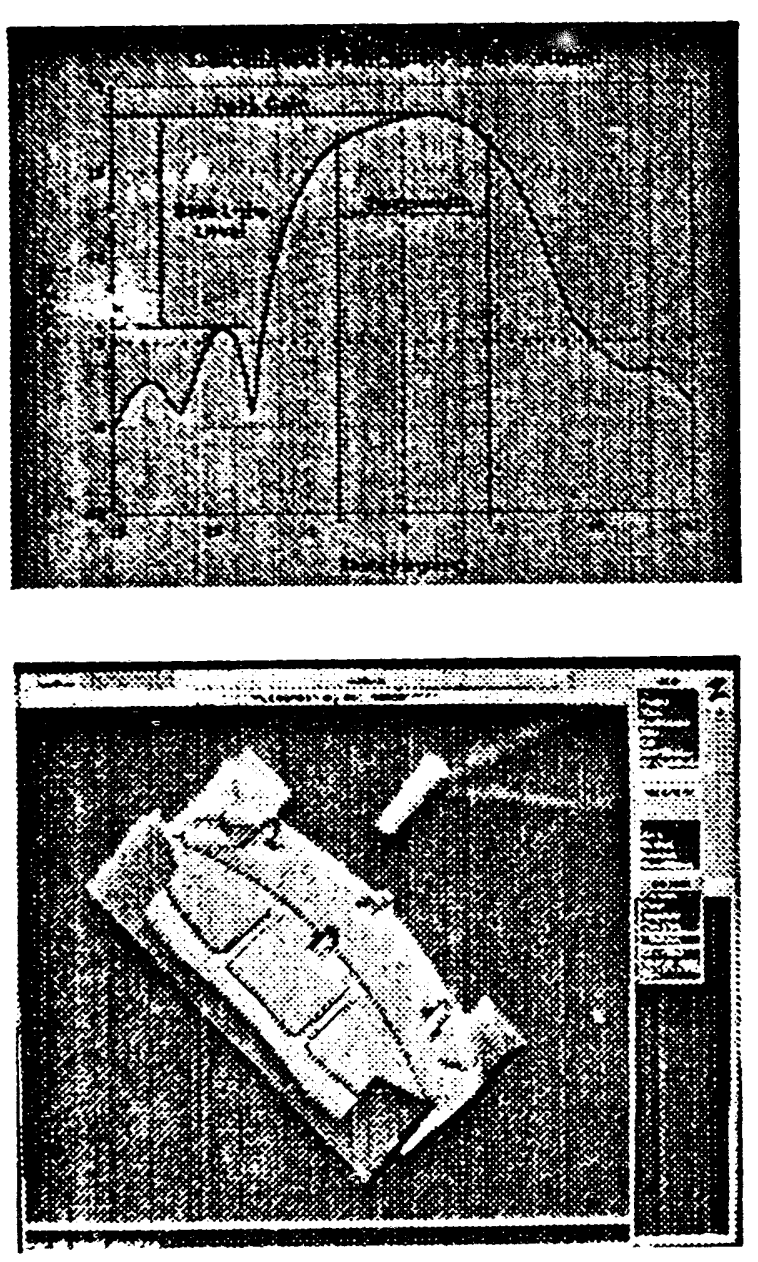

\section{Virtual Prototyping}

Physical Optics Model

Computer Iteration of Design

\section{Rapid Design \\ CAD Using Pro/ENGINEER}

Paperless Product

Definition

Simulation of Manufacture 
[1]

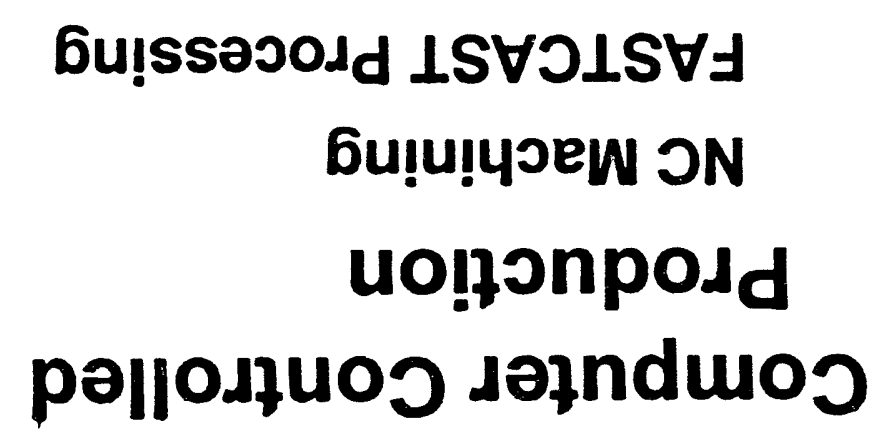

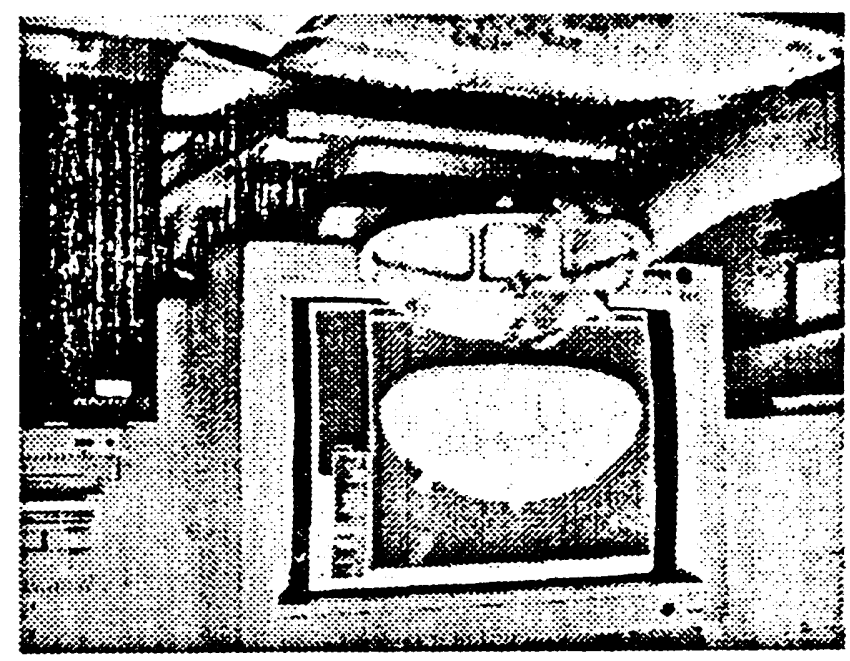

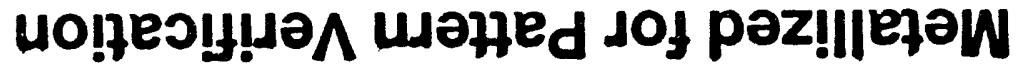

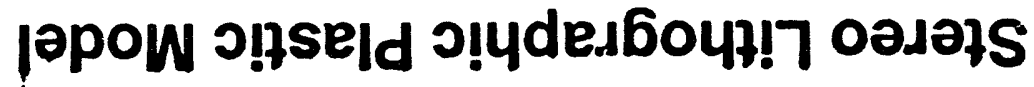

6u!|әроw Y007-Үग!no

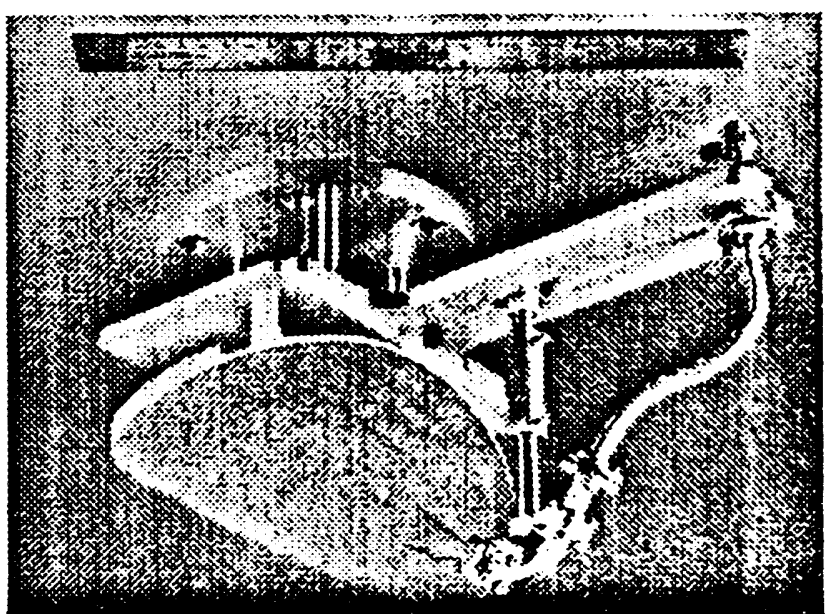

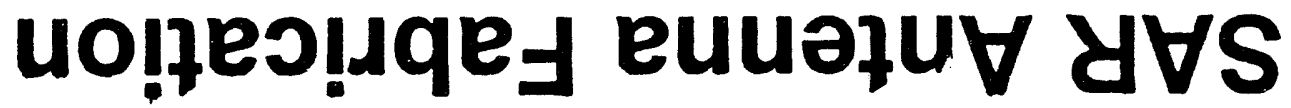




\section{SAR Antenna Design Validation}

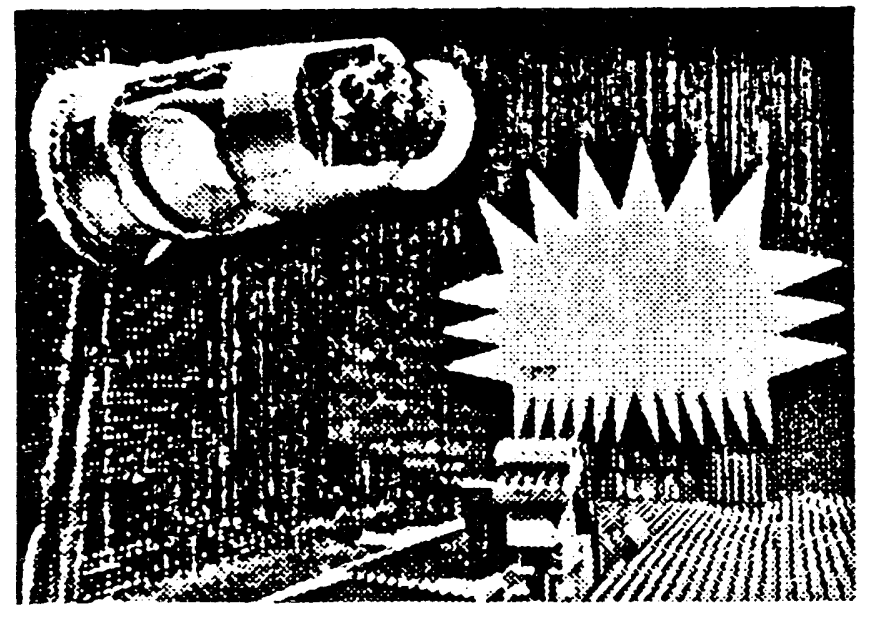

Automated Antenna

Pattern Measurements

Automated Impedance

Measurements

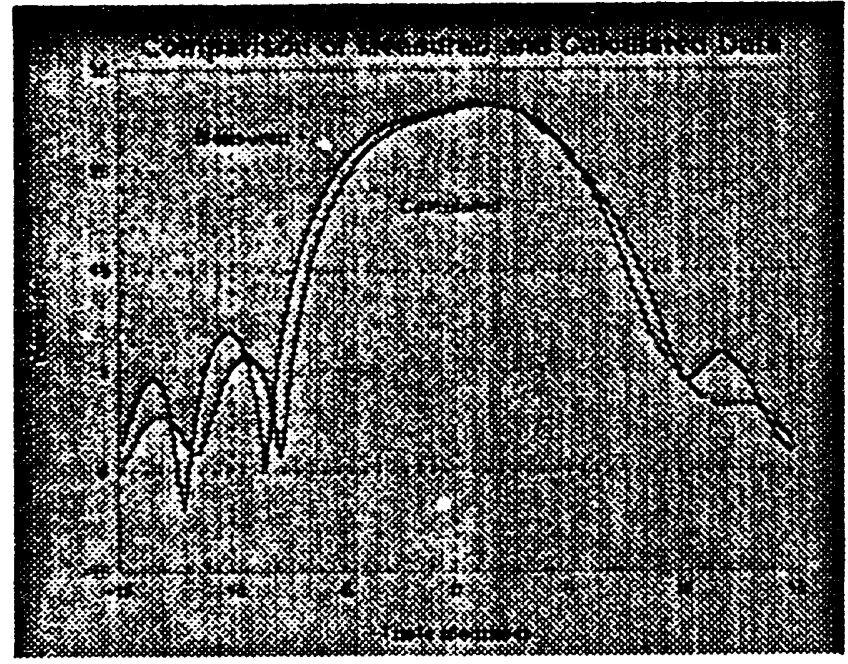

Confirmation of Antenna Gain, Beamwidths, Sidelobes 


\section{Antenna Measurements}

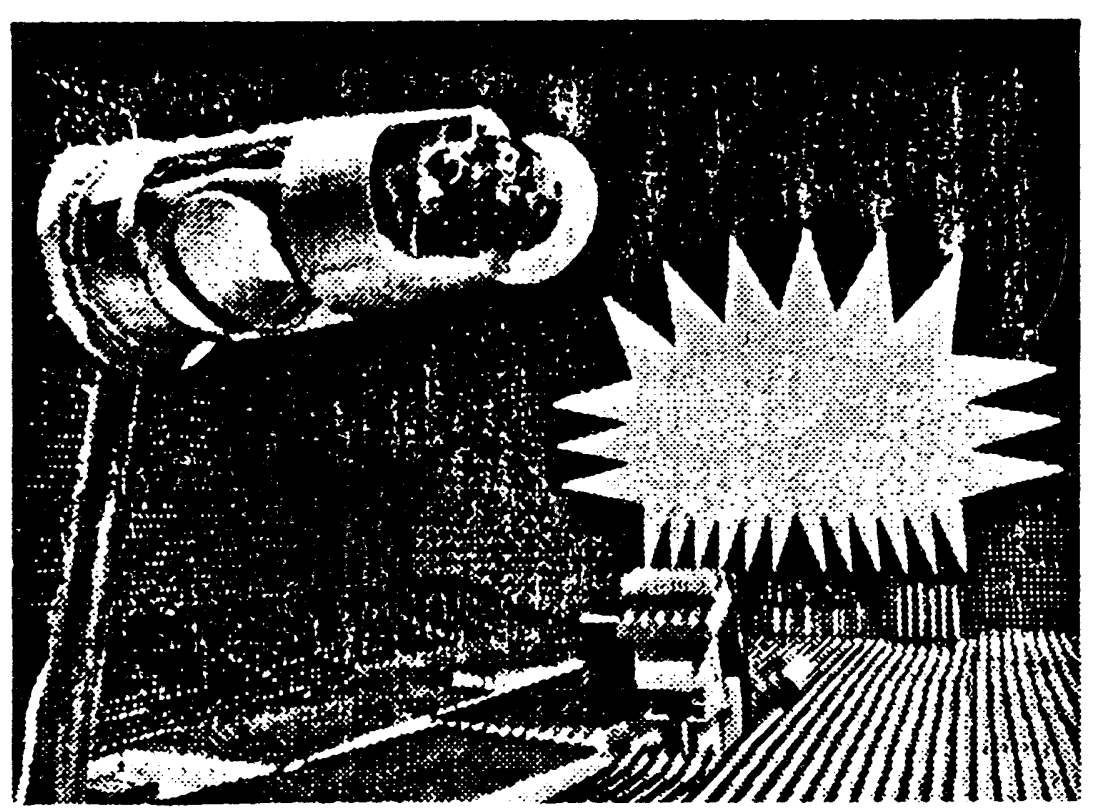

- Fully Polarimetric

- Wideband (1.0 - 40.0 GHz)

- Measurement Zone Size: 6'x6'x6'
- Resolution: < 0.5 inches

- Foam Column, Ogive, Mast Model Target Support

- Fully-focused, 2-D ISAR Imaging 


\section{RCS Measurements}

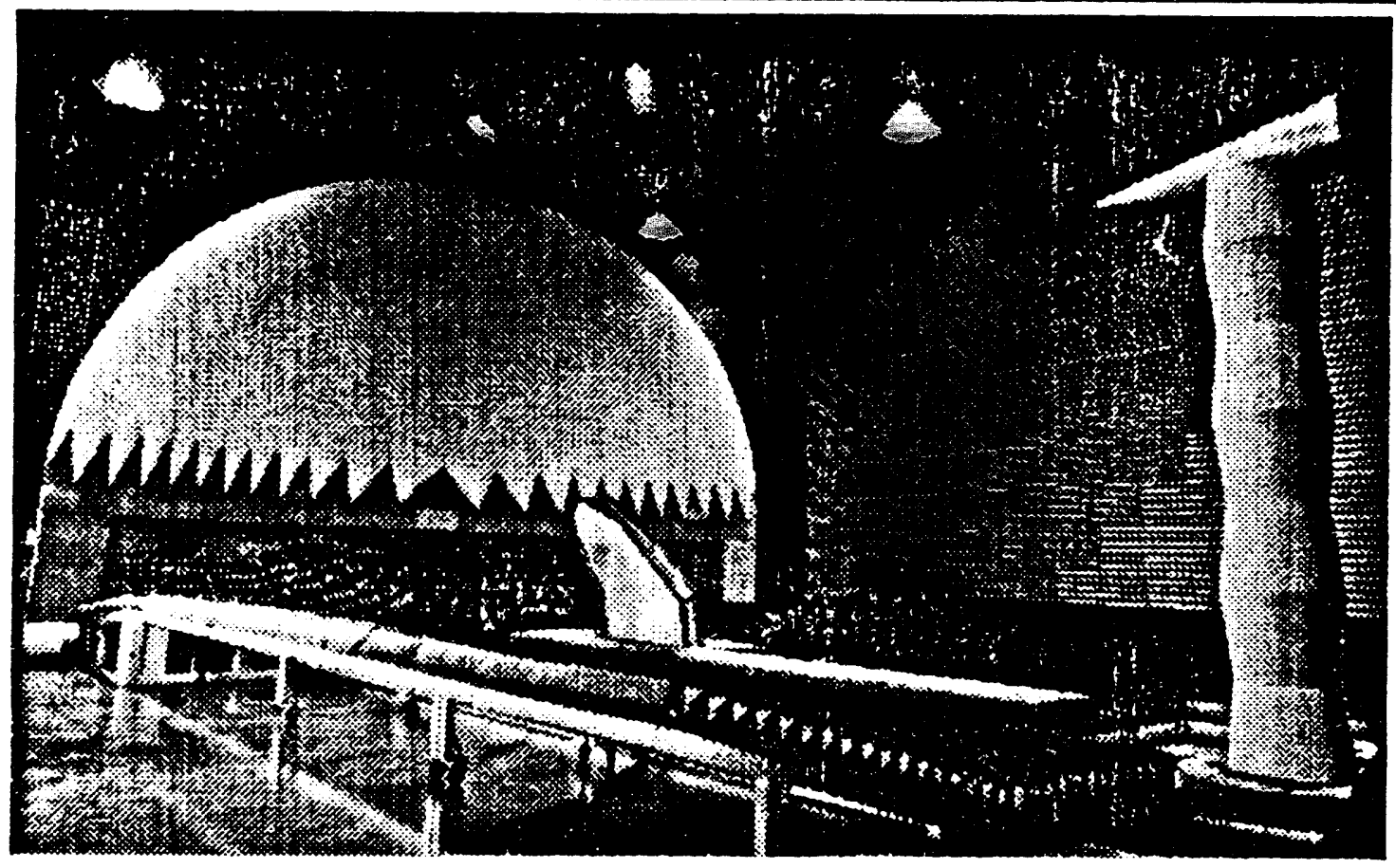

- Fully Polarimetric

- Resolutions to 0.5 inches

- Fully-focused, 2-D ISAR Imaging
- Measurement Zone Size: 6'x6'×6'

- Wideband (1.0 - 40.0 GHz) (2.0 - 18.0 GHz continuous) 

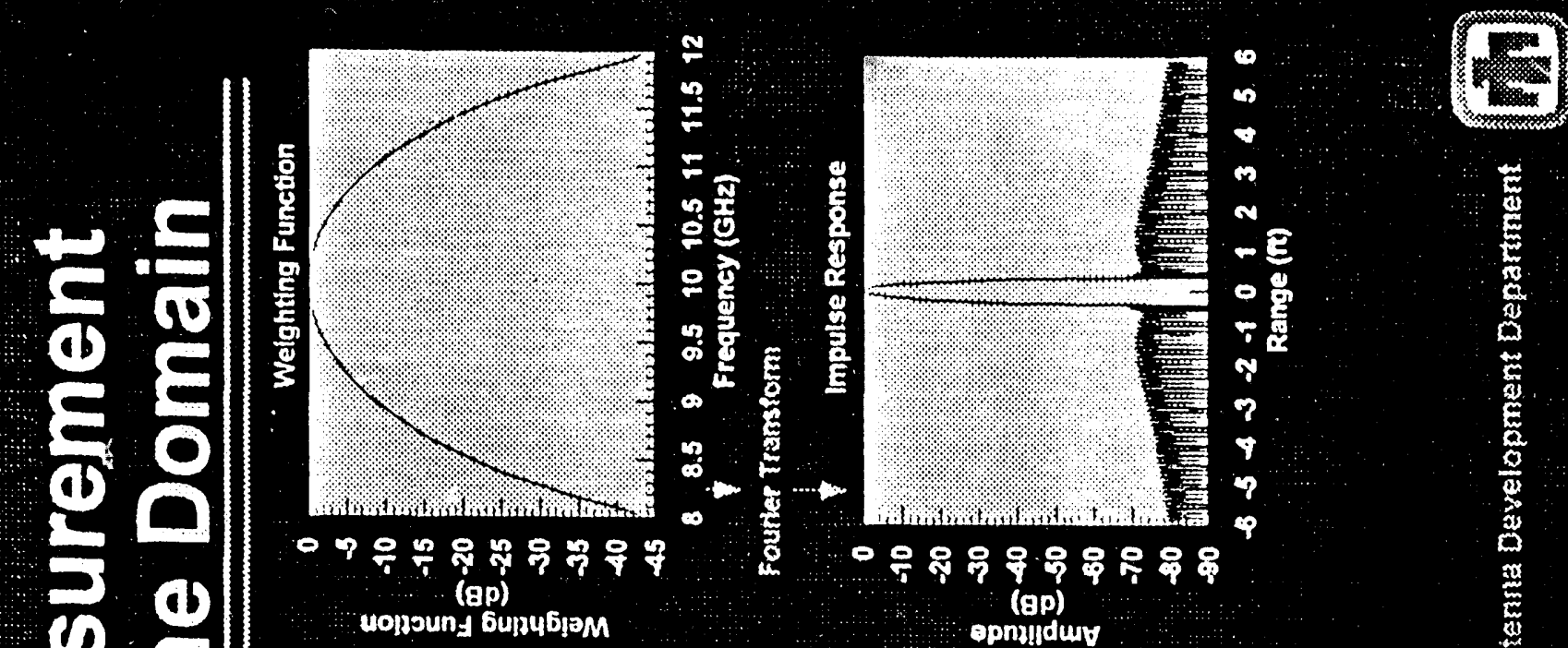

$=0$
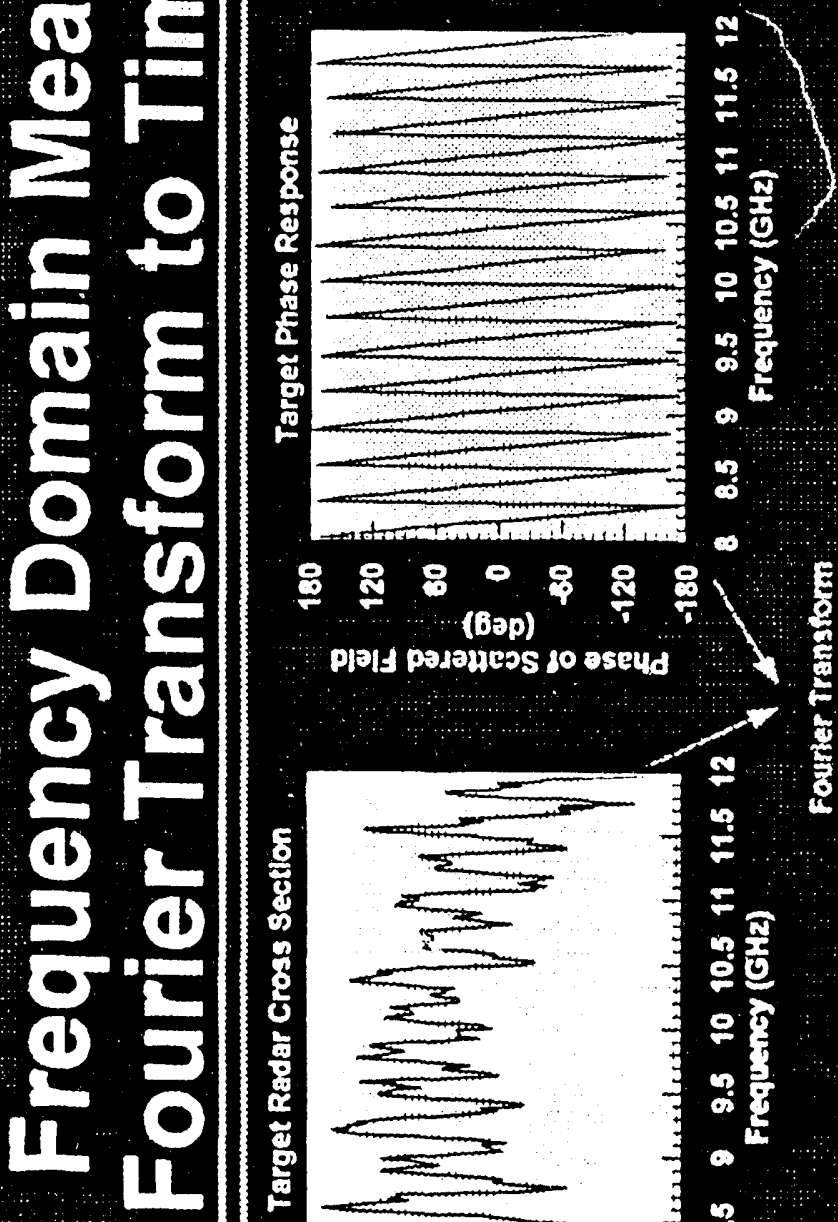

$8 \% 808$ \& 8

plafl paspess 10 aseud

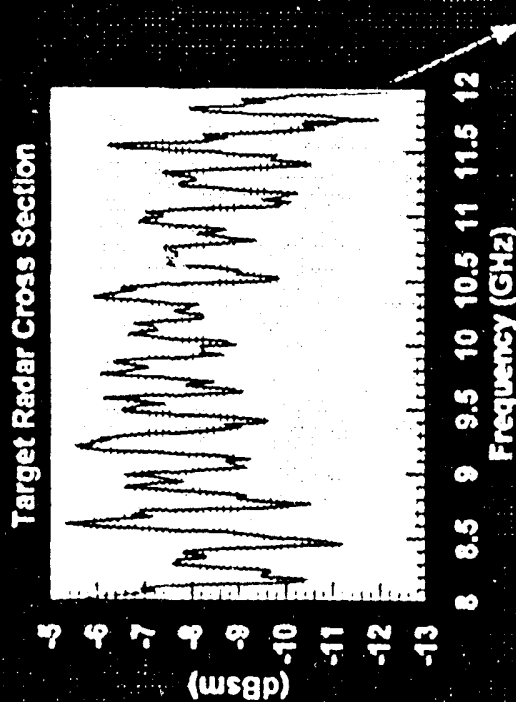

uchess s5010 deper:

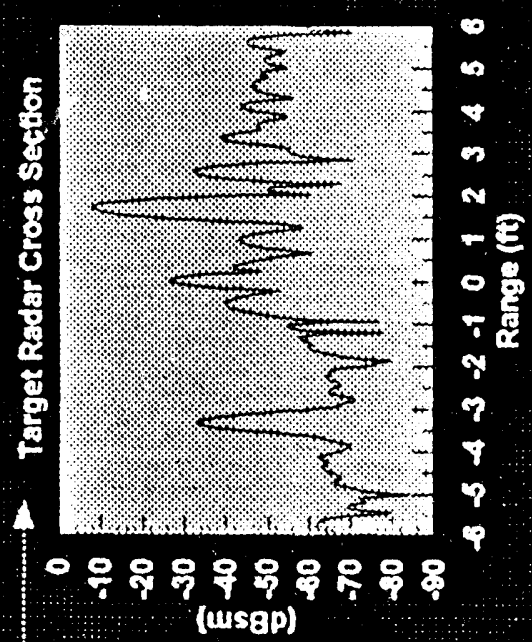

uoposs ssous sepey

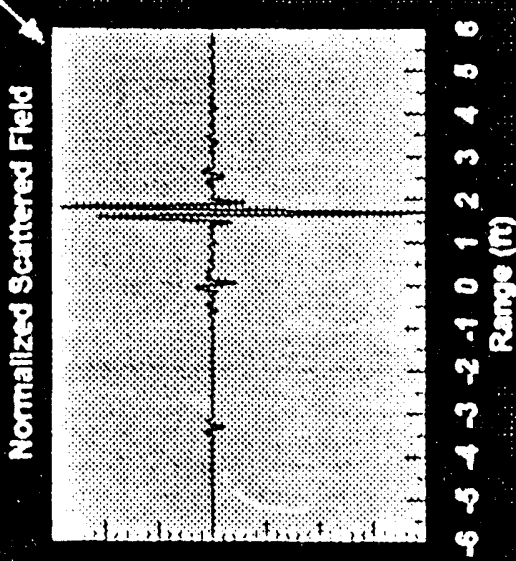

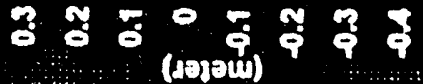
prat pazkewow 
Amp labe c3em)

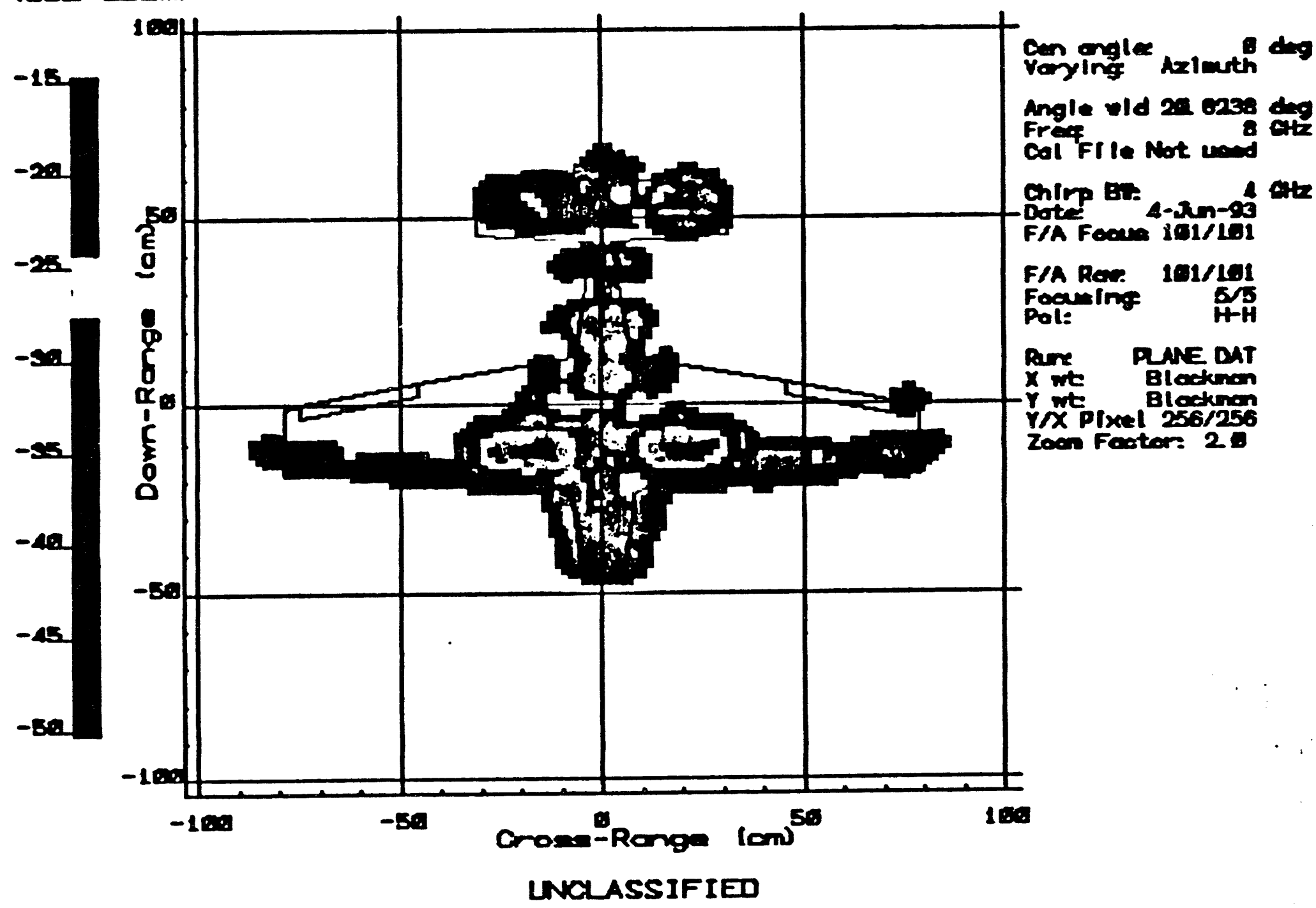




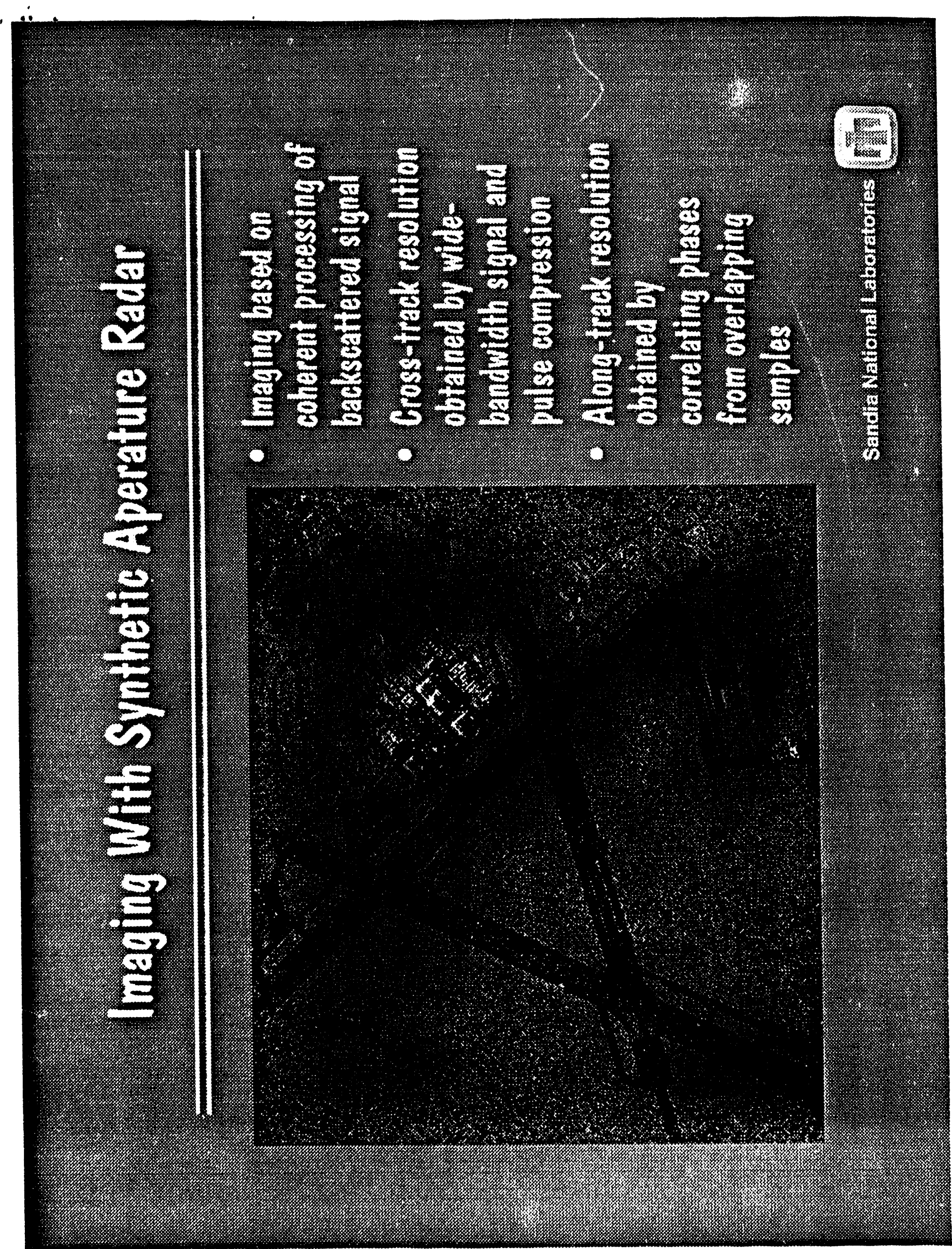




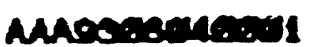

Ju 4 195 47 1903

UNCLASSIFIED

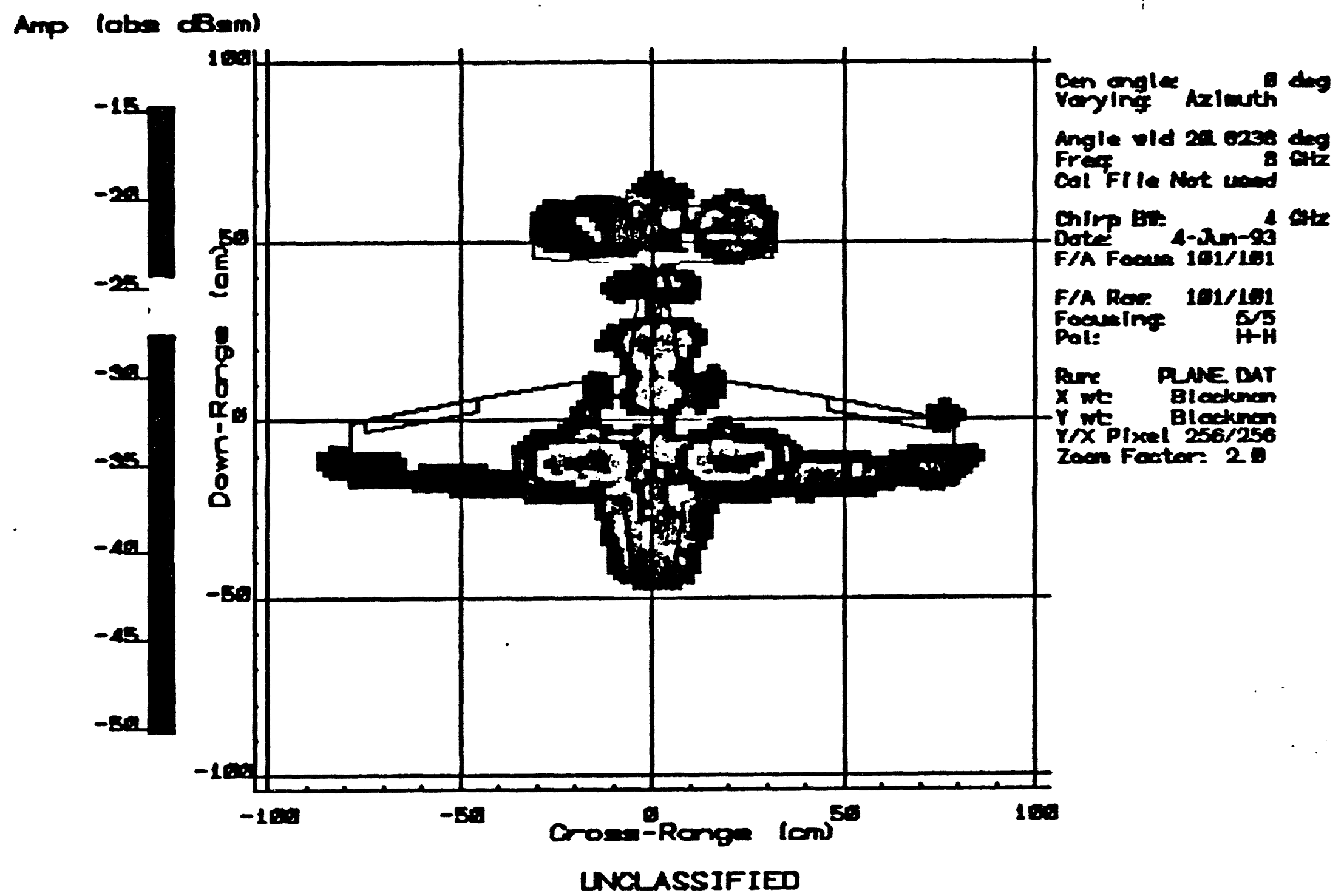




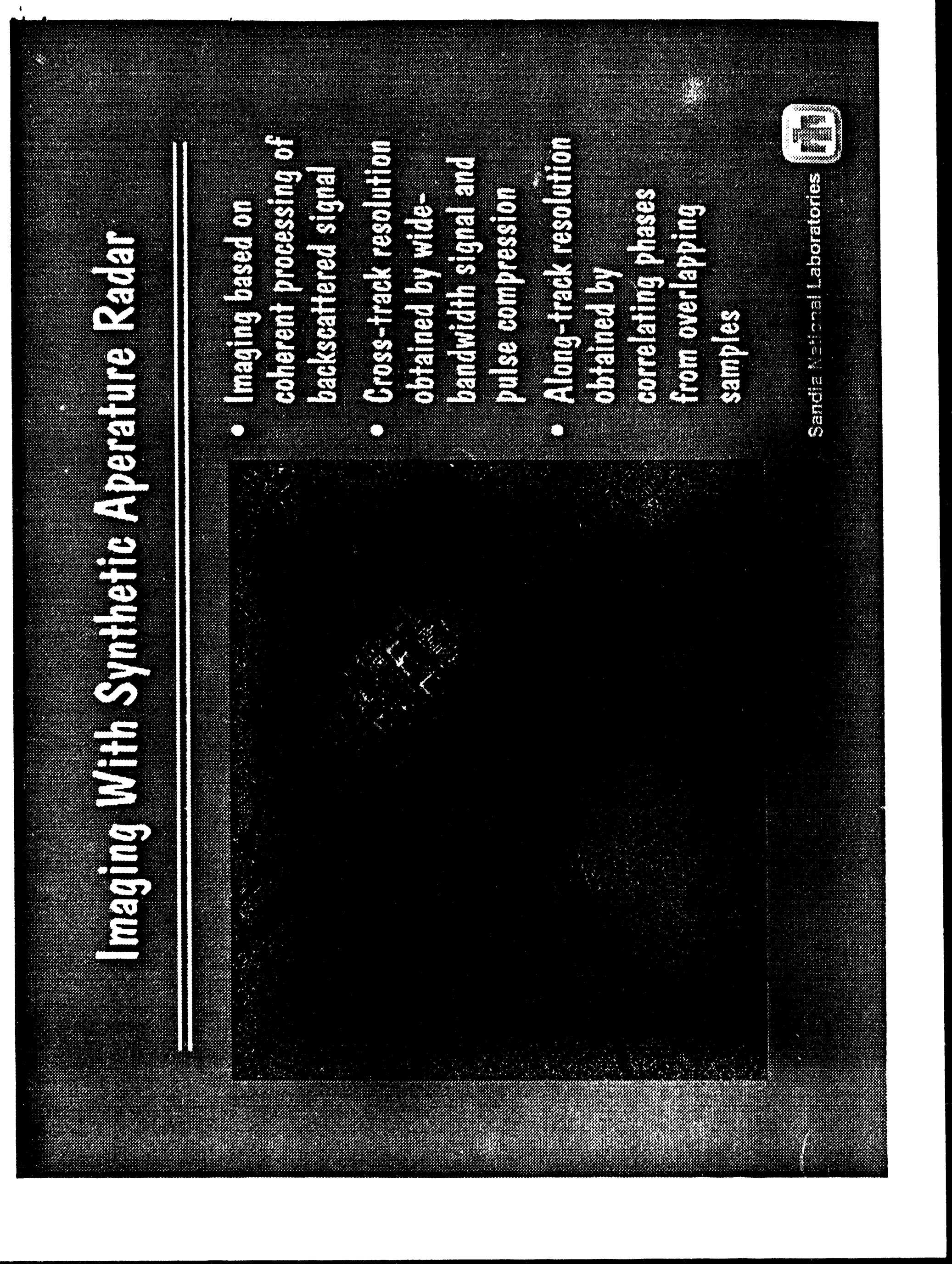


11
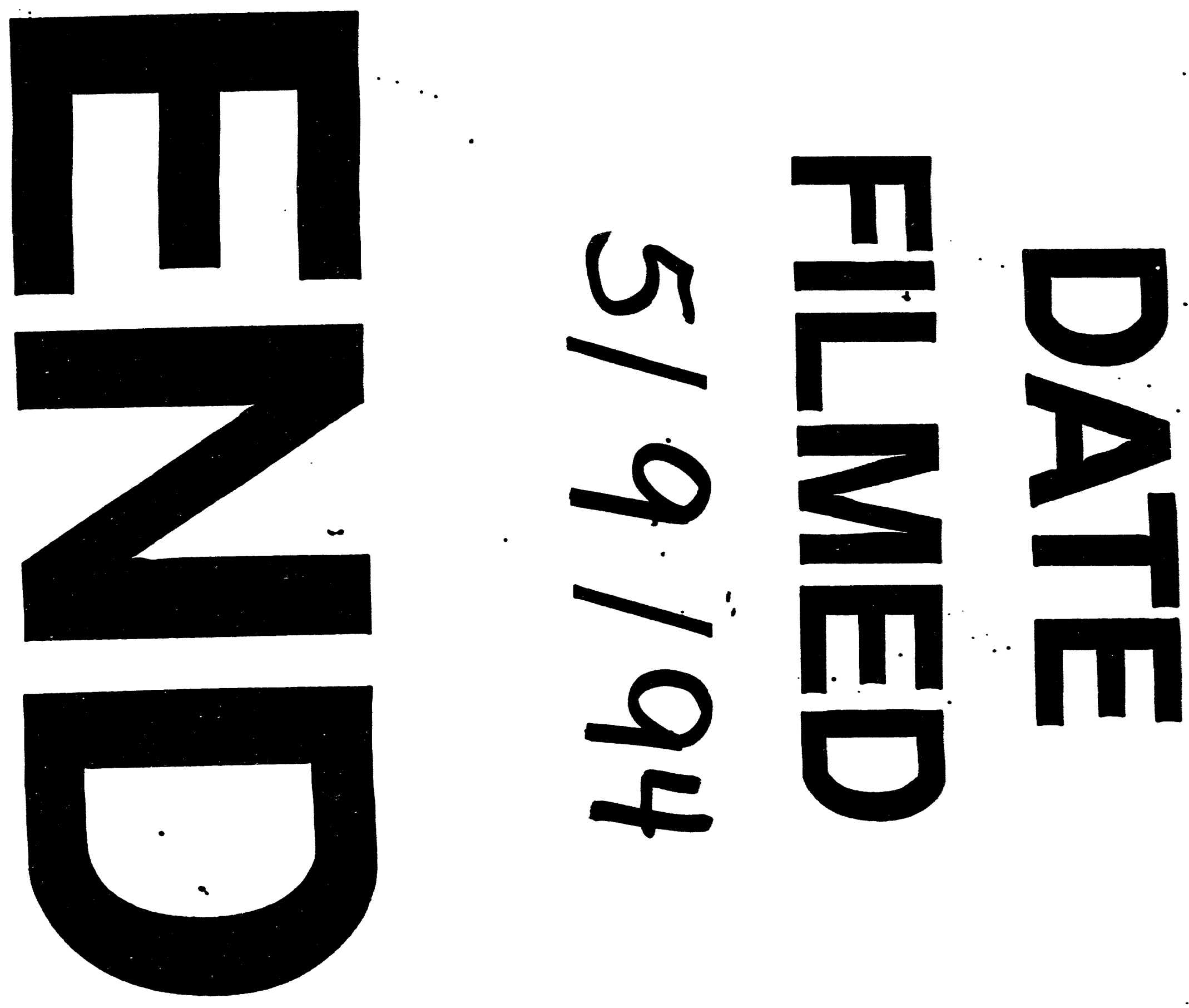


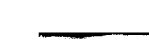
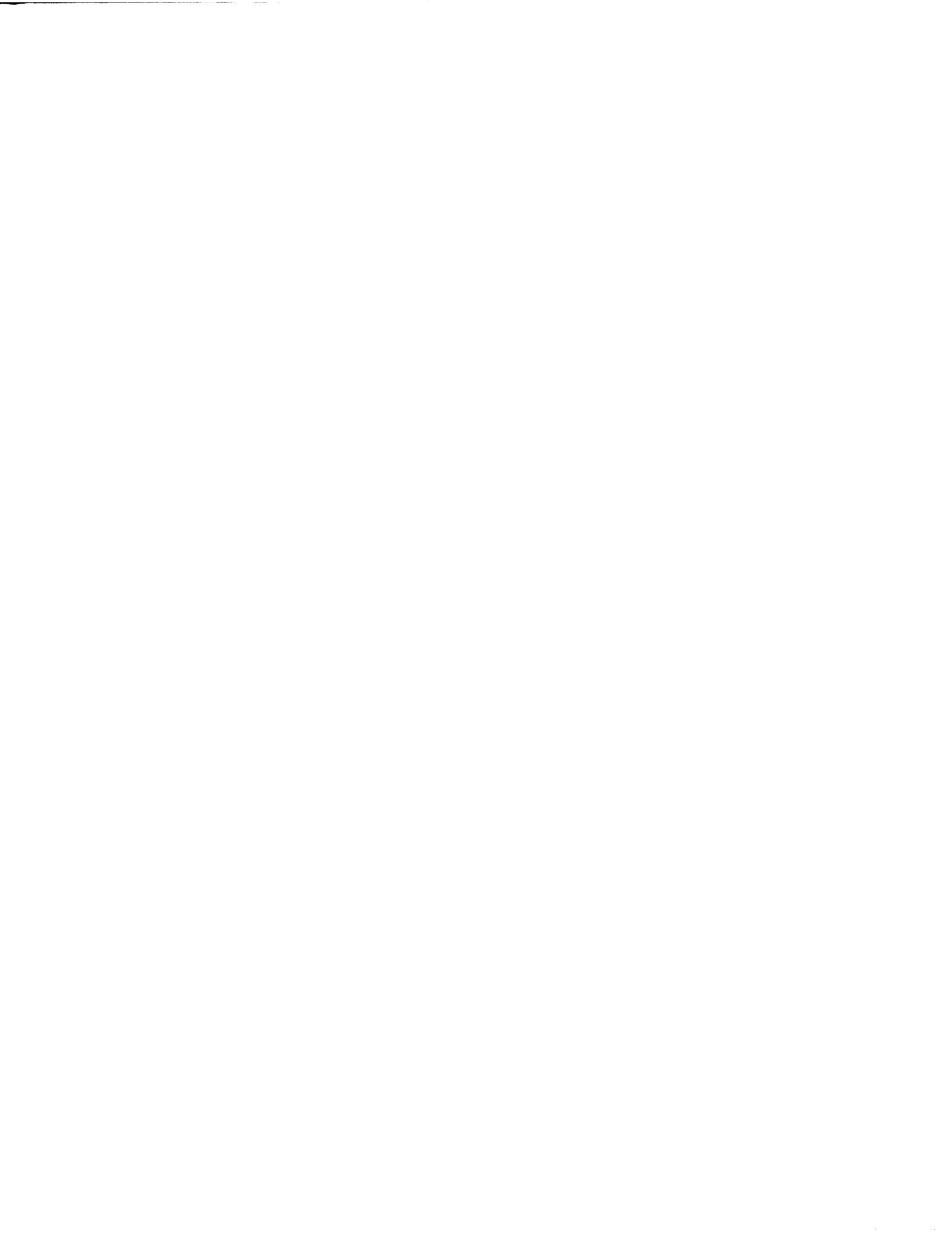